\title{
A Review on Electrolytes for Aqueous Zinc-Ion Batteries
}

\author{
Woosuk Kang, Changshin Jo ${ }^{\dagger}$ \\ School of Chemical Engineering and Materials Science, Chung-Ang University, \\ 84 Heukseok-ro, Dongjak-gu, Seoul 06974, Republic of Korea
}

\section{수계 아연 이차전지 전해질 연구 개발 동향}

\author{
강우석, 조창신 ${ }^{\dagger}$ \\ 중앙대학교 화학신소재공학부
}

(Received February 22 2021; Accepted February 24 2021)

\begin{abstract}
Growing attention to eco-friendly and sustainable energy sources makes people focus on the improvement of grid-scale energy storage systems. Lithium ion batteries have demerits for these applications due to the use of flammable non-aqueous electrolytes. With this regard, aqueous electrolytes have been actively investigated because of its safe property, fast charge/discharge rate capability, easy preparation process, non-toxicity, and eco-friendliness. Among many candidates for aqueous battery system, zinc ion has attracted considerable interests. Zinc has advantages of abundance, low redox potential, and high volumetric capacity. However, when used in alkaline electrolytes, several problems such as dendritic growth, formation of irreversible intermediates and capacity fade hamper its practical use. Even though mild acidic electrolytes were used to suppress dendritic growth, the corrosion of zinc anode and current collectors still depressed the cycling stability. Herein, we introduce recent studies on electrolytes for aqueous zinc ion battery revealing their principles, working mechanism and research goals.
\end{abstract}

\section{1. 서론}

화석연료 사용으로 인한 각종 환경문제가 심각해짐에
따라 친환경적/경제적이며 지속 가능한 에너지원에 관 한 관심이 계속해서 커지고 있다. 이에 화석연료에 대 한 의존성을 낮추고 지속 가능한 에너지원의 개발을 목

${ }^{\dagger}$ Corresponding Author: Changshin Jo

E-mail: changshin@cau.ac.kr 


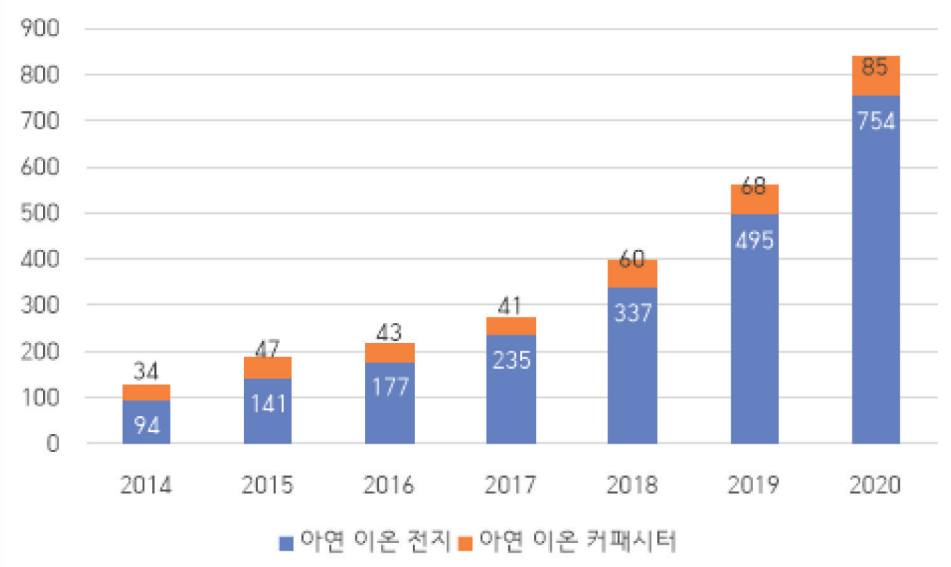

Figure 1. The number of researches on zinc-based energy storage devices for recent years.

표로, 전 세계적으로 신재생 에너지 및 에너지 저장장 치 관련 연구를 활발히 수행하고 있다. 가장 대표적인 에너지 저장장치로, 수십 년간 연구가 진행된 리튬 이 온 이차전지(Lithium ion battery, LIB)는 높은 에너 지밀도와 우수한 수명특성으로 인해 소형 전자기기부터 전기자동차, 대용량 에너지 저장장치(Energy storage system, ESS) 등에 활발히 사용되고 있다. 하지만, 누 액, 팽창, 부반응, 폭발의 위험성 등의 고질적인 안전성 문제가 여전히 해결되어야 할 과제이며 리튬, 전이금속 전구체 등의 원료에 대해서는 제한된 매장량, 높은 가 격, 가격 불안정에 따른 자원의 무기화 등의 문제가 존 재한다.

이에 리튬 이온 기반 에너지 저장장치를 대체하려는 시도가 활발히 진행되고 있다. 먼저 소듐 $(\mathrm{Na})$, 포타슘 (K) 이온 전지 등의 알칼리 금속 이차전지는 소재의 풍 부한 매장량과 낮은 가격의 장점이 있지만 큰 이온 반 지름, 전극 소재와의 낮은 가역 용량 및 좁은 반응 전 압 등으로 리튬 이온 이차전지에 비해 낮은 에너지밀도 를 나타낸다. 또 다른 이온으로, $\mathrm{Mg}^{2+}, \mathrm{Ca}^{2+}, \mathrm{Zn}^{2+}, \mathrm{Al}^{3+}$ 와 같은 다가 금속이온 전지(multivalent metal-ion batteries)에 대한 연구도 활발히 수행되고 있다. 다가 이온 이차전지는 다가 양이온과 반응하는 양극재를 사 용했을 때 한 이온이 복수 전하와 반응에 참여한다는 장 점이 있다. ${ }^{1}$ 하지만, 이때 생기는 강한 정전기적 상호작 용이 고체상 확산(solid-state diffusion)을 저해하므
로 빠르고 가역적인 이온의 삽입/탈리(intercalation/ deintercalation) 과정을 방해한다. ${ }^{2}$ 게다가 전극/전해 질 계면에서 용해된 다가 이온은 이온 주위를 둘러싸며 상호작용하는 용매 껍질(solvent shell)로부터 강한 정 전기적 힘을 받아 탈용매과정이 방해되며, 이는 다가 이 온의 전극 물질 내 삽입 과정을 방해한다. 이러한 현상 을 탈용매 불이익(desolvation penalty)이라 일컫고, 다 가 이온 기반 이차전지의 성능 향상을 위해서 극복해야 할 장애물로 여겨진다. ${ }^{3)}$

한편, 불규칙적으로 발생하는 태양, 풍력, 해양, 지열 에너지 등과 같은 신재생 에너지의 효율적인 저장을 위 하여 ESS에 대한 필요성이 커지고 있다. 소형화를 중요 시하는 LIB와는 다르게 $\mathrm{ESS}$ 는 부피/무게에 대한 제약 이 덜해 낮은 생산단가와 보수/유지 비용이 중요한 요소 로 여겨지며, 높은 에너지밀도, 빠른 충 · 방전 속도, 높 은 안정성을 요구한다. 이를 만족하는 차세대 에너지 저 장장치로서 수계 아연 이온 이차전지(aqueous zinc ion battery, AZIB)가 주목을 받고 있다. 특히, $\mathrm{AZIB}$ 는 그 리드 시스템에 적용하기 적합한 후보 에너지 저장장치로 많은 연구가 진행되었다. 실제로, 최근 몇 년간 아연 이 온을 활용한 수퍼커패시터(supercapacitor)나 이차전지 에 관한 연구의 수가 급격하게 증가하고 있다. (그림 1)

가연성이 있어 충·방전 과정에서 발생한 산소 기체 와 더불어 화재의 위험성을 초래하는 유기용매 전해질 과 비교했을 때, ${ }^{4} \mathrm{AZIB}$ 는 다음과 같은 장점들이 있다. 
먼저, 물을 전해질 용매로 사용하기 때문에 전지의 장기 간 사이클 이후, 단락(short circuit) 문제가 발생하더라 도 발화 위험이 없어 안전한 구동이 보장된다. 게다가, 수계 전해질은 독성이 없고 유기용매에 비해 빠른 이온 전도 특성을 보이기도 한다. 또한, 아연 금속은 다전자 교환과, 높은 밀도 $\left(25^{\circ} \mathrm{C}\right.$ 에서 $\left.7.13 \mathrm{~g} \mathrm{~cm}^{-3}\right)$ 를 가져, 리튬 금속 음극의 3 배에 이르는 높은 부피당 용량 $(5851 \mathrm{mAh}$ $\mathrm{cm}^{-3}$ )을 가지며 낮은 산화 환원 전위[-0.76 V vs 표준 수소 전극(standard hydrogen electrode, SHE)]로 인 해 넓은 작동 전압 및 높은 에너지밀도 달성이 가능하다 는 큰 장점도 지닌다. ${ }^{5,6)}$ 이외에도, 아연은 지구상에 풍 부한 물질로 친환경적이고 원가가 저렴하다는 장점이 있는데, 아연 금속의 매장량은 리튬 금속의 매장량보다 3000 배 많은 것으로 알려져 있다. ${ }^{7)}$

전기화학적 에너지 저장장치는 양극, 음극, 전해질, 분리막으로 구성되어 있으며, 이중 전해질은 아연 이 온을 양 전극으로 운송하는 역할을 한다. 또한, 전기화 학적으로 안정한 반응 전압 영역을 결정하면서 쿨롱 효 율(Coulombic efficiency)에 영향을 미쳐 결국 전지 의 성능에 직접 영향을 준다. 최근 아연 금속 음극의 안 정화, ${ }^{8-10)}$ 아연과 반응하는 고용량 양극 소재 개발 연 구와 $^{11-13)}$ 더불어, 수계 액체 전해질, 이온성 액체(ionic liquid) 전해질, 유기 전해질, 겔 전해질 등 수많은 전해 질에 관한 연구가 진행되고 있다. ${ }^{14-17)}$ 먼저, 연구 초기 에는 $\mathrm{KOH}$ 기반의 알칼리계 전해질이 주로 사용되었으 나, ${ }^{18)}$ 낮은 쿨롱 효율과 아연 수지상(dendrite) 형성에 따른 안정성 문제, 아연 산화물 부산물 생성, 빠른 용량 저하 문제가 발생하여 실용성이 떨어졌다. 중성 또는 약 산성의 수계 전해질의 경우, 알칼리계 전해질과는 다르 게 AZIB에 수지상 형성으로부터 방해받지 않는 등, 더 적합함을 보였으나 쿨롱 효율과 반응 전압 영역대가 더 개선되어야 할 필요가 있다. 가장 보편적으로 사용되는 전해질인 $\mathrm{ZnSO}_{4}$ 수용액과 $\mathrm{Zn}\left(\mathrm{CF}_{3} \mathrm{SO}_{3}\right)_{2}$ 수용액은 낮은 쿨롱 효율을 가지며, 전기화학 반응 중 양극 물질이 전 해질에 용해되고 비가역적인 부반응까지 수반해 용량 손실의 문제점을 가진다. ${ }^{7,19,20)}$

앞서 언급한 바와 같이 전해질은 $\mathrm{AZIB}$ 의 성능에 직접
적인 영향을 주기 때문에 다양한 형태의 전해질 연구가 활발히 진행되고 있다. 따라서, 본 총설 논문에서는 아 연 이온 기반의 전기화학적 에너지 저장장치와 관련하 여 연구된 최근 논문 중, 전해질에 관한 연구를 집중적 으로 소개하고, 주제별로 나눠 다루고자 한다. AZIB에 적용을 위한 1) 다양한 전해질의 소개와 2) 수계기반 전 해질에서의 물 분해를 억제해 작동 전압 영역(working voltage range)을 넓힌 연구, 3) 겔 전해질의 도입, 4) 첨가제의 활용 전략, 나아가 전반적인 연구 동향 및 방 향성에 대해서 언급하고자 한다.

\section{2. 수계액체 전해질(Aqueous liquid electrolyte)}

수계 액체 전해질은 물을 용매로 사용하는 전해질을 일컫는다. 연구 초기에는 $\mathrm{KOH}$ 를 염으로 사용한 알칼리 계 전해질을 주로 사용했다. 이후에 중성 또는 약산성의 $\mathrm{ZnSO}_{4}$ 수용액과 같이 아연 이온 $\left(\mathrm{Zn}^{2+}\right)$ 을 전하 운반체로 사용하는 아연 염 전해질은 재 충 - 방전이 가능하고, 오 랜 충 - 방전이 가능하며, 가격이 낮은 장점이 있다. 또 한, 수계 전해질의 전극/전해질 계면에서의 전하 운송 저항(Charge transfer resistance, $\mathrm{R}_{\mathrm{CT}}$ )이 비수계의 값 보다 현저하게 낮아, 빠른 출력특성을 나타낸다. 예를 들어 Nazar 연구 그룹의 연구결과에 따르면, ${ }^{3)}$ 아연 금 속을 상대 전극으로, 층상 구조의 $\mathrm{V}_{3} \mathrm{O}_{7} \cdot \mathrm{H}_{2} \mathrm{O}$ 물질을 작 업 전극으로 구성한 전기화학 전지에서 $\mathrm{R}_{\mathrm{CT}}$ 값을 비교한 결과, 비수계 전해질에서 저항이 15-100배 크게 나타났 다. 그러나 수계 기반 전해질의 경우 물 분해 반응 $(1.23$ $\mathrm{eV})$ 으로 인해 비수계(유기계) 전해질을 사용하는 유기 계 아연 이차전지(2-3 V)와 비교하여 작동 전압이 낮아 결과적으로 이차전지의 에너지밀도가 낮아지는 문제가 있다. 게다가, 중성이거나 약산성의 수계 전해질은 아연 이온 수지상 형성을 억제하고 망간 기반 양극재에 안정 적인 구동을 가능하게 해 $\mathrm{AZIB}$ 에 적합하다고 알려졌으 나 여전히 아연 음극이나 집전체가 산성 전해질로부터 부식하게 되면서 사이클 안정성을 악화시킨다. ${ }^{21)}$

이번 장에서는 먼저 AZIB관련 연구에 주로 사용되는 전해질 염의 종류와 농도에 따른 특성, 약산성 전해질 
(a)

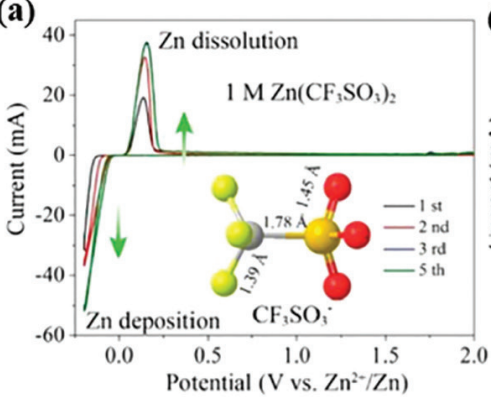

(b)

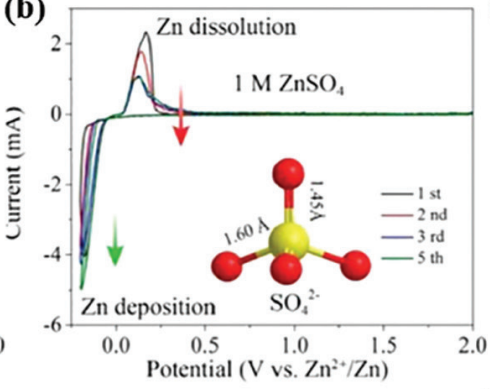

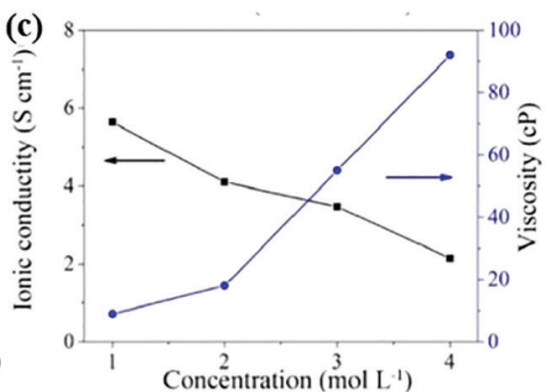

Figure 2. Cyclic voltammograms of $\mathrm{Zn}$ electrode in aqueous electrolyte of (a) $1 \mathrm{M} \mathrm{Zn}\left(\mathrm{CF}_{3} \mathrm{SO}_{3}\right)_{2}$ and (b) $1 \mathrm{M} \mathrm{ZnSO}_{4}$ at the scan rate of $0.5 \mathrm{mV} \mathrm{s}^{-1}$ between -0.2 and 2.0 V. Reproduced from Zhang et al. J. Am. Chem. Soc. 2016;138:12894-12901, with permission of American Chemical Society [14].

Table 1. Onset potential and Coulombic efficiency (CE) values from $\mathrm{CV}$ analysis (Figure 2) for $\mathrm{Zn}_{(}\left(\mathrm{CF}_{3} \mathrm{SO}_{3}\right)_{2}$ and $\mathrm{ZnSO}_{4}$ electrolytes. Reproduced from Zhang et al. J. Am. Chem. Soc. 2016;138:12894-12901, with permission of American Chemical Society [14].

(a) $1 \mathrm{M} \mathrm{Zn}\left(\mathrm{CF}_{3} \mathrm{SO}_{3}\right)_{2}$

\begin{tabular}{c|c|c|c}
\hline Cycle number & $\begin{array}{c}\text { Plating } \\
\text { potential (V) }\end{array}$ & $\begin{array}{c}\text { Stripping } \\
\text { potential (V) }\end{array}$ & $\begin{array}{c}\text { Coulombic } \\
\text { efficiency }\end{array}$ \\
\hline 1st & -0.140 & 0.050 & $73 \%$ \\
\hline 2nd & -0.110 & 0.045 & $96 \%$ \\
\hline 3rd & -0.070 & 0.044 & $100 \%$ \\
\hline 5th & -0.070 & 0.044 & $100 \%$ \\
\hline
\end{tabular}

조건에서의 수지상 형성 등을 소개하고, $\mathrm{AZIB}$ 의 성능 향상을 위한 전해질 염의 고농도화 전략 연구 중 흥미로 운 결과를 소개하고자 한다.

\section{1 전해질 염의 종류}

$\mathrm{AZIB}$ 는 주로 아연 금속을 음극으로 사용하고, 양극 재로는 망간, 바나듐 기반 물질을 사용하여 연구되고 있 다. 전해질로는 $\mathrm{ZnSO}_{4}$ 또는 $\mathrm{Zn}\left(\mathrm{CF}_{3} \mathrm{SO}_{3}\right)_{2}, \mathrm{Zn}\left(\mathrm{NO}_{3}\right)_{2}$, $\mathrm{Zn}\left(\mathrm{ClO}_{4}\right)_{2}, \mathrm{ZnCl}_{2}, \mathrm{Zn}\left(\mathrm{CH}_{3} \mathrm{COO}\right)_{2}, \mathrm{Zn}\left(\mathrm{BF}_{4}\right)_{2} \cdot \mathrm{xH}_{2} \mathrm{O}$, $\mathrm{Zn}\left(\mathrm{N}\left(\mathrm{CF}_{3} \mathrm{SO}_{2}\right)_{2}\right)_{2}\left(\mathrm{Zn}(\mathrm{TFSI})_{2}\right)$ 와 같은 염들이 주로 사용 되었다. ${ }^{62-26)}$ 이 중에서도 $\mathrm{ZnSO}_{4}, \mathrm{Zn}\left(\mathrm{CF}_{3} \mathrm{SO}_{3}\right)_{2}$ 는 부 식성이 강한 $\mathrm{Cl}^{-}$나 $\mathrm{NO}_{3}{ }^{-}$를 포함하지 않아 충 - 방전 중 아연 음극을 안정화한다. Chen 연구 그룹은 양이온 결 핍성 스피넬 구조 $\mathrm{ZnMn}_{2} \mathrm{O}_{4}$ 를 양극으로 활용한 전지에 서, $\mathrm{ZnCl}_{2}, \mathrm{ZnNO}_{3}, \mathrm{ZnSO}{ }_{4}, \mathrm{Zn}\left(\mathrm{CF}_{3} \mathrm{SO}_{3}\right)_{2}$ 을 아연 염으 로 사용해 각 전해질의 농도에 따른 결과를 비교했다. 그중 $1 \mathrm{M}$ 의 $\mathrm{ZnSO}_{4}$ 와 $1 \mathrm{M}$ 의 $\mathrm{Zn}\left(\mathrm{CF}_{3} \mathrm{SO}_{3}\right)_{2}$ 전해질이 각 (b) $1 \mathrm{M} \mathrm{ZnSO}_{4}$

\begin{tabular}{c|c|c|c}
\hline Cycle number & $\begin{array}{c}\text { Plating } \\
\text { potential (V) }\end{array}$ & $\begin{array}{c}\text { Stripping } \\
\text { potential (V) }\end{array}$ & $\begin{array}{c}\text { Coulombic } \\
\text { efficiency }\end{array}$ \\
\hline 1st & -0.170 & 0.055 & $71 \%$ \\
\hline 2nd & -0.140 & 0.052 & $66 \%$ \\
\hline 3rd & -0.130 & 0.050 & $53 \%$ \\
\hline 5th & -0.110 & 0.050 & $48 \%$ \\
\hline \multicolumn{4}{|r}{}
\end{tabular}

각 전기화학 반응 중 물 분해로 인한 산소 발생 반응을 억제하면서 구동 전압 영역대를 $2.3 \mathrm{~V}$ 이상으로 넓힌 다는 것을 보였다. ${ }^{14)}$ (그림 $2 \mathrm{a}, \mathrm{b}$ ) 또한, 아연이온의 더 가역적인 증착/용해 반응을 이끌었으며, $\mathrm{Zn}\left(\mathrm{CF}_{3} \mathrm{SO}_{3}\right)_{2}$ 의 농도가 올라감에 따라 이온 전도도는 감소하고 점도 는 증가했는데(그림 $2 \mathrm{c}$ ), 이는 고농도에서의 높은 점도 가 용매화 및 전하 운송 경향을 바꾸면서 안정성을 강화 하기 때문이다. 또한, 고농도의 염은 물의 활성도와 물 로부터의 부반응을 낮춰 높은 사이클 안정성을 가져다 준다. 한편, $\mathrm{Zn}\left(\mathrm{CF}_{3} \mathrm{SO}_{3}\right)_{2}$ 는 $\mathrm{ZnSO}_{4}$ 와 비교했을 때 쿨롱 효율이 점차 증가해 3 번째 사이클 이후에는 $100 \%$ 에 이 르지만 $\mathrm{ZnSO}_{4}$ 의 경우에는 각 사이클마다 쿨롱 효율이 낮았고 사이클이 지날수록 감소하는 경향을 보였다. (표 1) 이는 $\mathrm{CF}_{3} \mathrm{SO}_{3}{ }^{-}$음이온이 부피가 커서(bulky) 아연 양 이온을 감싸는 물 분자의 수를 줄여 용매화 효과를 낮춰 주므로 아연 양이온의 운송을 촉진했다고 설명한다.

이와 비슷하게, Shuquan Liang 그룹은 $\mathrm{ZnSO}_{4}$, 
$\mathrm{ZnCl}_{2}, \mathrm{Zn}\left(\mathrm{CH}_{3} \mathrm{COO}\right)_{2}, \mathrm{Zn}\left(\mathrm{NO}_{3}\right)_{2}$ 의 네 가지 전해질을 사용하고, $\mathrm{ZnSO}_{4}$ 전해질의 여러 농도 조건에서 $\mathrm{V}_{2} \mathrm{O}_{5}$ 양 극을 사용해 전기화학적 성능을 평가했다. ${ }^{6)}$ 네 가지 염 을 각각 $3 \mathrm{M}$ 의 농도로 제조해 테스트한 결과로, $\mathrm{ZnSO}_{4}$ 가 가장 높은 가역 용량과 오랜 기간의 사이클을 보였 다. 이는 나머지 세 염의 음이온 $\left(\mathrm{CH}_{3} \mathrm{COO}^{-}, \mathrm{NO}_{3}^{-}, \mathrm{Cl}^{-}\right)$ 의 부식성과 같은 불안정성에 기인한다. $\mathrm{ZnSO}_{4}$ 의 농도 구배에 따른 결과를 알아보기 위해 $0.5 \mathrm{M}, 1 \mathrm{M}, 1.5 \mathrm{M}$, $2 \mathrm{M}, 2.5 \mathrm{M}, 3 \mathrm{M}$ 의 $\mathrm{ZnSO}_{4}$ 전해질이 평가되었는데, 3 $\mathrm{M}$ 의 $\mathrm{ZnSO}_{4}$ 전해질이 $0.5 \mathrm{~A} \mathrm{~g}^{-1}$ 에서 100 사이클 이후에 $128 \mathrm{mAh} \mathrm{g}^{-1}$ 의 가역 용량을 보이며 가장 뛰어난 성능을 보였다. 게다가, 초기 쿨롱 효율은 $67 \%$ 이었지만 수 사 이클 이후의 쿨롱 효율은 98\%까지 상승하였다.

이 외에도 $\mathrm{Zn}(\mathrm{TFSI})_{2}$ 를 전해질 염으로 활용한 연 구결과가 있다. Liqiang Mai 연구진은 층상 구조의 $\mathrm{Fe}_{5} \mathrm{~V}_{15} \mathrm{O}_{39}\left(\mathrm{OH}_{9}\right) \cdot 9 \mathrm{H}_{2} \mathrm{O}$ 양극재의 성능을 평가하기 위해 전해질로 $\mathrm{Zn}(\mathrm{TFSI})_{2}$ 를 사용하였는데, $\mathrm{ZnSO}_{4}$ 와 비교했 을 때 장기간의 사이클에서도 용량을 더 잘 유지하는 경 향을 보였다. ${ }^{27)}$ 이는 앞의 $\mathrm{Zn}\left(\mathrm{CF}_{3} \mathrm{SO}_{3}\right)_{2}$ 전해질의 경우 와 유사하게 $\mathrm{Zn}(\mathrm{TFSI})_{2}$ 전해질 속에 부피가 큰 $\mathrm{TFSI}^{-}$ 음이온이 아연 이온 $\left(\mathrm{Zn}^{2+}\right)$ 을 감싸는 물 분자의 수를 줄 여 용매화 효과를 감소시킴으로써 아연 양이온의 운송 이 빨라져 더 안정적인 전기화학적 성능을 보여준다고 설명된다.

\section{2 금속 수지상 형성}

$\mathrm{KOH}$ 기반 알칼리계 전해질에서의 아연 금속 전지는 음극에서 생기는 수지상 형성이라는 고질적인 문제점을 가져서 수명특성에 치명적인 단점을 가지고 있다. 수지 상 형성은 계속해서 자라나게 되면 일부가 음극에서 떨 어져 나와 전해질과 부반응 함으로써 더는 활물질로 사 용되지 못할 뿐만 아니라, 양극에 맞닿으면 전지의 단락 (short circuit)을 일으키기도 한다. 또한, $\mathrm{KOH}$ 기반 알 칼리계 전해질에서의 아연 수지상은 아연산염이 불활성 $\mathrm{ZnO}$ 층으로 분해되어 균일한 이온 확산과 증착을 방해 하면서 문제를 일으킨다. ${ }^{31)}$ 반면에 중성 또는 약산성의 조건에서는 아연 수지상이 뾰족하게 자라나는 리튬 수 지상이나 알루미늄 수지상과는 다르게 아연 이온 확산 의 운동학적 요소(kinetic factor)에 의해 $2 \mathrm{D}$ 구조의 육 각 평판 모형으로 성장하는 경향이 있어 보다 안정적이 다. (그림 3) 이처럼 중성이거나 약산성인 전해질에서의 수지상 형성은 알칼리계 전해질에서 보다는 완화된 결 과를 보이지만, 음극 표면에서의 수소 발생 반응으로 인 한 $\mathrm{pH}$ 변화는 불활성의 아연산염 $\left(\mathrm{Zn}(\mathrm{OH})_{4}{ }^{2-}\right)$ 의 형성을 촉진하면서 결국 수명 성능에 영향을 미치고, 이는 아 연 수지상 문제를 악화시킬 수 있다. ${ }^{30,32)}$ 게다가, 높은 전류밀도에서는 과전압이 증가해 수지상 형성을 촉진할 수 있으므로 해결되어야 할 문제로 남아 있다.

수지상 형성을 억제하는 전해질 개질 전략으로 첨가 제의 활용을 통한 전기장 유도식 아연 증착, 타 금속-아
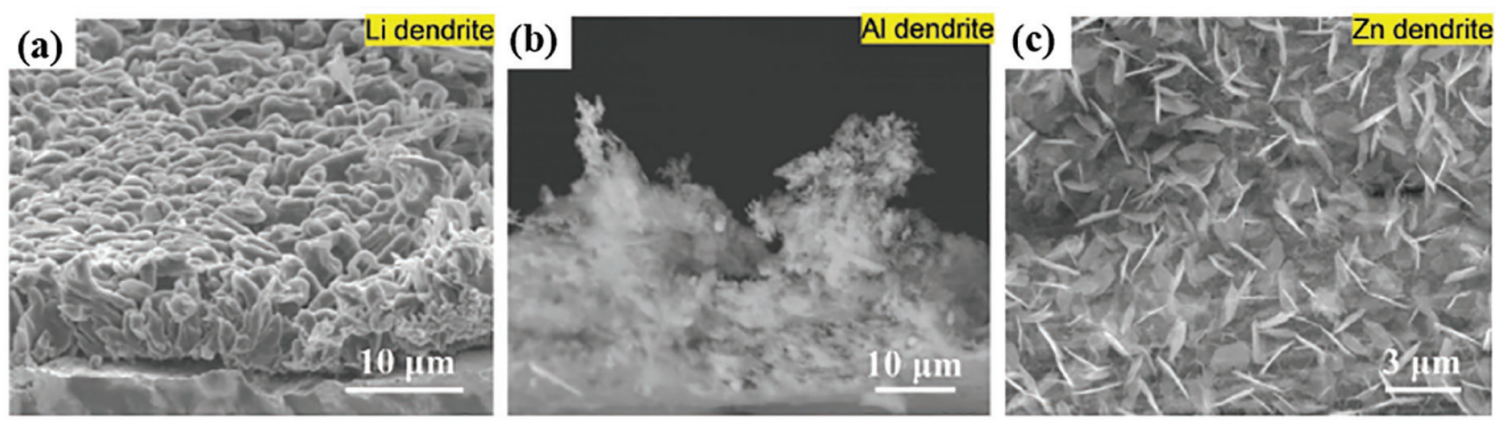

Figure 3. contrast of topologies between Zn dendrite and its counterparts (Li, Al). (a) SEM image of Li dendrite. Reproduced from Zheng et al. ACS Energy Lett. 2016;1:1247-1255, with permission of American Chemical Society [28]. (b) SEM observation of Al dendrite. Reproduced from Chen et al. ACS Appl. Mater. Interfaces 2017;9:22628-22634, with permission of American Chemical Society [29]. (c) SEM image of Zn dendrite. Reproduced from Yang et al. Adv. Mater. 2020;32:2001854, with permission of John Wiley and Sons [30]. 
연 합금(alloy) 형성을 통한 영역 선택적 결정핵 생성 유 도, 겔 전해질 활용을 통한 물리적 억제 등과 같은 방법 들이 있는데 이러한 전략들은 장 3 에서 자세하게 소개하 고자 한다.

\section{3 고농도 전해질}

수계 전해질의 빠른 충 - 방전 특성과 뛰어난 안정 성 등의 장점에도 불구하고, 물 분해 반응의 위험성으 로 인한 좁은 범위의 작동 전압 $(\langle 2 \mathrm{~V})$ 은 전극의 산화 환 원 반응이 이 영역대 안에서 일어나야 하므로 전극 활 물질의 선택폭을 줄이고, 전지의 에너지밀도를 제한시 킨다. ${ }^{11,33)}$ 작동 전압 영역대를 넓히는 방법으로, 전해 질 내 염의 농도를 대폭 증가시킨 접근 방식이 보고되었 다. Chunsheng Wang과 연구진은 수계 리튬 이온 전 지에서 $21 \mathrm{M}$ 의 LiTFSI 전해질을 사용해 수계 전해질 에서의 고농도화 전략을 처음으로 제시했다. ${ }^{34)}$ 물이 먼 저 환원되어 수소가 발생하는 보통의 전해질과는 달리, 고농도의 전해질에서는 $\mathrm{TFSI}^{-}$음이온이 최초용해껍질 (primary solvation sheath)에 존재하고 $\mathrm{TFSI}^{-}$가 우선 적이고 지배적으로 환원이 되는 반응을 보이면서 물의 환원을 늦춰 더 낮은 전위에서 물이 환원되게 함으로써 넓어진 작동 전압 영역대를 가능하게 한다.

Chunsheng Wang 그룹은 이러한 원리를 적용해 수 계 아연 이온 전지에도 고농도화 전략을 사용한 연구 를 진행했다. ${ }^{35)} 1 \mathrm{M}$ 의 $\mathrm{Zn}(\mathrm{TFSI})_{2}$ 와 $20 \mathrm{M}$ 의 LiTFSI를 혼합한 고농도의 전해질은 거의 $100 \%$ 의 쿨롱 효율을 달성하는 가역적인 구동을 보였다. 비교군으로 $1 \mathrm{M}$ 의 $\mathrm{Zn}(\mathrm{TFSI})_{2}$ 와 $5 \mathrm{M}$ 의 LiTFSI 전해질을 혼합한 전해질에 서는 6 개의 물 분자가 $\mathrm{Zn}^{2+}$ 이온을 둘러싸면서 $\mathrm{TFSI}^{-}$의 영향이 적었다. 중간 비교군인 $1 \mathrm{M}$ 의 $\mathrm{Zn}(\mathrm{TFSI})_{2}$ 와 10 $\mathrm{M}$ 의 LiTFSI 전해질에서는 $\mathrm{Zn}^{2+}$ 이온의 최초용해껍질을 채우기 시작했고, 고농도인 $1 \mathrm{M}$ 의 $\mathrm{Zn}(\mathrm{TFSI})_{2}$ 와 $20 \mathrm{M}$ 의 LiTFSI 전해질에서는 $\mathrm{Zn}^{2+}$ 이온 주위를 $\mathrm{TFSI}^{-}$가 둘 러싸 $\left(\mathrm{Zn}-\left(\mathrm{H}_{2} \mathrm{O}\right)_{6}\right)^{2+}$ 가 아닌 $(\mathrm{Zn}-\mathrm{TFSI})^{+}$의 이온쌍을 형 성하면서 TFSI 이온이 물의 환원을 저해해 수소 발생 을 막고 안정적인 아연 도금/박리 반응을 유도했다. 또 다른 전해질의 고농도화 연구로, Jia-Xing Jiang과 연
구진은 $30 \mathrm{M}$ 의 $\mathrm{ZnCl}_{2}$ 전해질을 사용했다. ${ }^{36)}$ 가격이 높 은 불소화 염 기반 전해질들과 비교했을 때 $\mathrm{ZnCl}_{2}$ 염은 상대적으로 저렴하다. 일반적으로 묽은 $\mathrm{ZnCl}_{2}$ 수용액은 $\left(\mathrm{Zn}\left(\mathrm{OH}_{2}\right)_{6}\right)^{2+}$ 나 $\left(\mathrm{Zn}\left(\mathrm{OH}_{2}\right)_{2} \mathrm{Cl}_{4}\right)^{2-}$ 와 같은 이온화 종들을 포함하지만, $30 \mathrm{M}$ 의 $\mathrm{ZnCl}_{2}$ 전해질에서는 모든 아연이 온이 팔면체 배위를 형성하는 데 필요한 $\mathrm{ZnCl}_{2} \cdot 1.8 \mathrm{H}_{2} \mathrm{O}$ 가 생성될 수 없다. 결과적으로 자유로운 물분자가 거 의 없게 되고 $\left(\mathrm{Zn}\left(\mathrm{OH}_{2}\right)_{6}\right)^{2+}$ 나 $\left(\mathrm{Zn}\left(\mathrm{OH}_{2}\right)_{2} \mathrm{Cl}_{4}\right)^{2-}$ 가 줄어 든다. 한편, $\mathrm{ZnCl}_{2}$ 의 농도가 증가함에 따라 $\left(\mathrm{ZnCl}_{4}\right)^{2-}$ 가 생겨나고 이는 전기화학적으로 비활성인 $\mathrm{Zn}(\mathrm{OH})_{2}$ 나 $\mathrm{ZnO}$ 같은 부산물의 생성을 억제한다고 설명한다. 작 동 전압 영역은 $5 \mathrm{M}$ 의 $\mathrm{ZnCl}_{2}$ 전해질에서 $1.6 \mathrm{~V}$ 를 나타 내던 결과가 $30 \mathrm{M}$ 의 $\mathrm{ZnCl}_{2}$ 전해질에서는 $2.3 \mathrm{~V}$ 값으로 증가함을 보였다. $30 \mathrm{M}$ 의 $\mathrm{ZnCl}_{2}$ 를 바나듐 산화물 양극 |아연 금속 음극 전지에 적용한 연구결과도 존재한다. Shumin Han과 연구진은 아연 금속을 음극으로 사용 하고 $\mathrm{Ca}_{0.20} \mathrm{~V}_{2} \mathrm{O}_{5} \cdot 0.80 \mathrm{H}_{2} \mathrm{O}$ 를 양극으로 사용하여 $1 \mathrm{M}$ 의 $\mathrm{ZnCl}_{2}$ 와 $30 \mathrm{M}$ 의 $\mathrm{ZnCl}_{2}$ 전해질을 사용하여 전기화학 성 능을 비교했다. ${ }^{37)}$ 고농도 전해질을 사용했을 때, 용량은 $296 \mathrm{mAh} \mathrm{g}^{-1}$ 에서 $496 \mathrm{mAh} \mathrm{g}^{-1}$ 으로 증가하면서 작동 전압 영역대도 $0.4 \mathrm{~V}$ 까지 넓어졌고, $50 \mathrm{~mA} \mathrm{~g}^{-1}(\mathrm{C} / 10)$ 의 낮은 전류밀도에서 100 사이클 이후의 용량 유지가 8.4\%에서 $51.1 \%$ 로 증가했다.

전해질의 고농도화 전략은 작동 전압 영역대를 높이 고 높은 가역성을 보장해주는 참신한 전략으로 여겨졌 지만 고농도화를 위해 필요한 많은 양의 고가의 전해질( 특히, $\mathrm{Zn}\left(\mathrm{CF}_{3} \mathrm{SO}_{3}\right)_{2}$, LiTFSI)이 공정단계에서의 단가를 높이고 이 때문에 실제로 적용되기는 어려운 측면이 있 다. 이를 해결하기 위해서는 값싼 전해질 염의 발견 및 높은 농도가 아니어도 탈용매 효과를 보장할 수 있는 첨 가제의 사용 등의 전략이 필요하다.

\section{3. 겔(gel) 전해질}

이차전지에서 겔 전해질은 강한 물리적 특성 때문에 금속 음극 표면에서의 수지상 형성을 억제하고, 활물질 이 용해되는 문제를 해결하기 위해 액체 전해질을 대체 
(a)

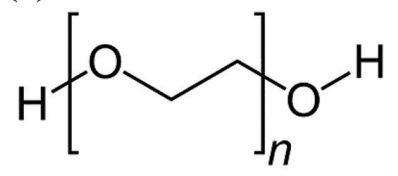

(c)

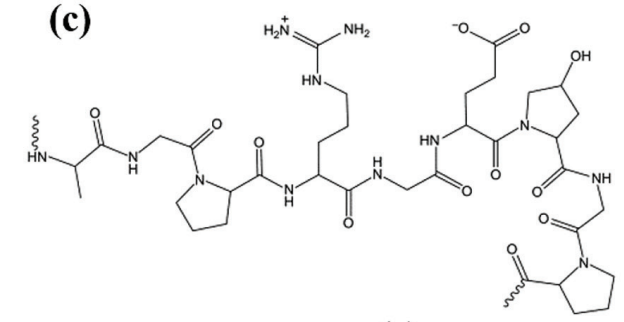

(e)

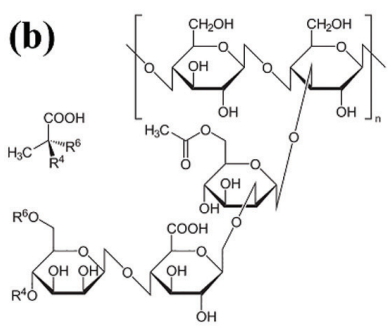

(d)

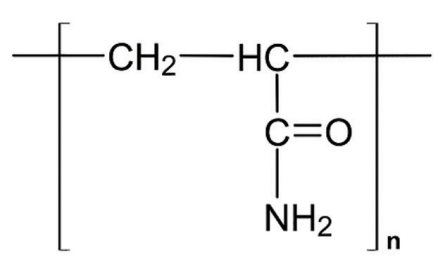

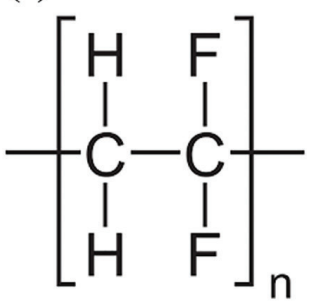

Figure 4. Molecular structures of (a) PEO, (b) Xanthan gum, (c) Gelatin, (d) PAM, and (e) PVDF

하여 사용된다. 또한, 기존 액체 전해질이 가지는 누수 문제가 없고, 전해질의 역할과 더불어 분리막의 역할을 동시에 수행함으로써 제조 공정이 간편화된다. 또한, 겔 전해질의 경우 구부러지는 특성으로 전지의 유연성을 더할 수 있다. 이러한 유연한 기계적 특성은 플렉서블, 웨어러블 기기 등의 에너지 저장 분야에 적용할 가능성 을 갖는다. ${ }^{38-40)}$

연구 초기의 아연 기반 전지에서는 아연 이온을 전도 하는 겔 전해질이 많이 발견되지 않아 LIB보다 연구가 활발하게 진행되지 않았다. 일반적으로 poly(ethylene oxide)(PEO) $-\mathrm{ZnX}_{2}\left(\mathrm{X}=\mathrm{Cl}, \mathrm{Br}, \mathrm{I}, \mathrm{ClO}_{4}, \mathrm{CF}_{3} \mathrm{SO}_{3}\right)$ 또는 poly(vinilydene fluoride)(PVDF)/PEO- $\mathrm{Zn}\left(\mathrm{CF}_{3} \mathrm{SO}_{3}\right)_{2}$ 와 같은 물질 조합을 사용한 연구가 보고되었지만, 이온 전도도가 낮고 $\left(10^{-5}-10^{-6} \mathrm{~S} \mathrm{~cm}^{-1}\right)$, 고분자의 분해가 빠 르며, 기계적 강도가 낮아 충 - 방전이 가능한 아연 전 지 구동에는 적합하지 않다. ${ }^{41,42)}$ 시간이 지나고 아연 이 온 전지에 관한 관심이 커지면서, 아연 금속 이차전지 에도 겔 전해질을 아연 이온 전지에 적용한 연구가 증 가했는데, 주로 비수계 또는 수계 액체 전해질에서 팽 창된 $\mathrm{PEO}$, 잔탄검(Xanthan gum), 젤라틴(Gelatin), polyacrylamide(PAM), PVDF 등과 같은 이온 전도성 고분자들이 연구되면서 비교적 높은 이온 전도도 $\left(10^{-4}-\right.$
$10^{-3} \mathrm{~S} \mathrm{~cm}^{-1}$ 를 보였다. ${ }^{43)}$ 또한, 다양한 음극 및 양극재 를 자가치유(self-healing)특성을 가진 고분자, 유연성 고분자 등의 겔 전해질과 결합해 활용성을 높이고, 겔 전해질의 열, 기계적 안정성 등을 확보하는 연구들이 보 고되었다. 이어지는 단락에서는 겔 전해질을 활용한 사 례를 소개하고자 한다.

\section{1 $\mathrm{PEO}$ 기반 고체 전해질}

$\mathrm{PEO}$ 는 $\mathrm{H}-\left(\mathrm{O}-\mathrm{CH}_{2}-\mathrm{CH}_{2}\right)_{\mathrm{n}}-\mathrm{OH}$ 의 구조를 가지는 고 분자 화합물로서, 유연한 결합 사슬을 가지고 에테르 (ether)기의 산소가 양이온과 상호작용함으로써 다양한 종류의 염들을 용해시킬 수 있다는 장점을 가져 리튬 이 온 전지의 고체 전해질로서 많이 사용되지만, 이온 전도 도가 높지 않다는 단점이 있다. ${ }^{44)}$ 아연 이온도 $\mathrm{PEO}$ 를 통 해 전도되어 전지에 적용될 수 있는데, 그 예로, Vickers 연구진이 $\mathrm{PEO}_{8} \cdot \mathrm{ZnBr}_{2}$ 전해질 기반 $\mathrm{Zn}-\mathrm{MnO}_{2}$ 전지를 제조해 안정성을 높였고, Amaratunga 연구진은 $\mathrm{PEO}$ 전해질에 $\mathrm{TiO}_{2}$ 세라믹 첨가제를 첨가해 이온 전도도와 기계적 안정성을 향상한 연구가 있다. ${ }^{45}{ }^{46)} \mathrm{Zn}-\mathrm{MnO}_{2}$ / $\mathrm{CNT}$ 시스템에 $\mathrm{TiO}_{2}$ 가 첨가된 $\mathrm{PEO}$ 전해질에서, $\mathrm{PEO}$ 의 결정상 형성이 억제되면서 이온 전도도를 높였다.

세라믹 첨가제 이외에, 아연 염을 $\mathrm{PEO}$ 전해질과 혼용 

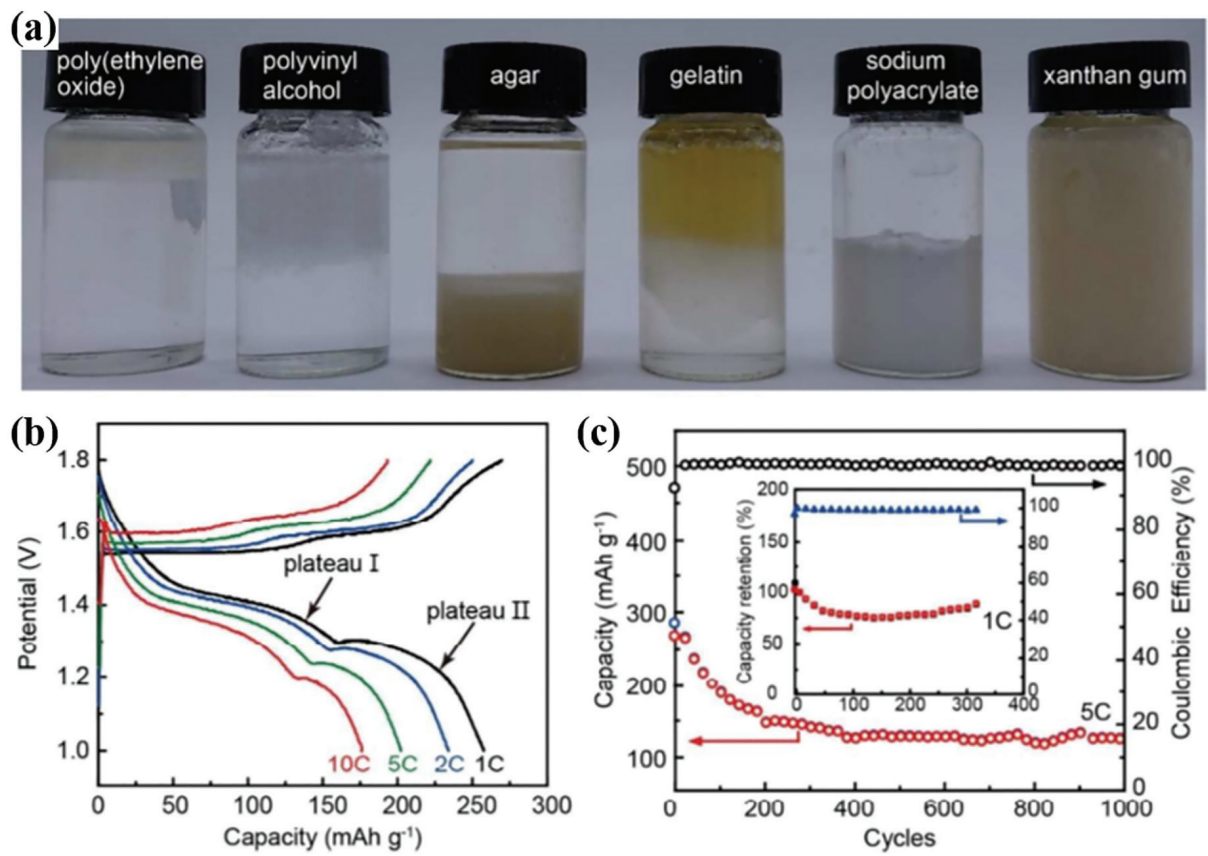

Figure 5. (a) Photograph of aqueous solutions of $2 \mathrm{M} \mathrm{ZnSO}_{4}$ and $0.1 \mathrm{M} \mathrm{MnSO}_{4}$ after adding $10 \mathrm{wt} \%$ polymers of PEO, polyvinyl alcohol(PVA), agar, gelatin, sodium polyacrylate and xanthan gum showing that PEO, PVA, agar, gelatin and sodium polyacrylate were aggregated while xanthan gum was uniformly dissolved in the solution. (b) Galvanostatic charge/ discharge profiles at different rates from $1 \mathrm{C}$ to $10 \mathrm{C}$. (c) Specific capacity and coulombic efficiency as a function of charge/discharge cycles at rates of $1 \mathrm{C}$ (inset) and $5 \mathrm{C}$, respectively. Reproduced from Zhang et al. J. Mater. Chem. A 2018;6:12337-12243, with permission of Royal Society of Chemistry [51].

하여 사용하는 전략도 보고되었다. Agrawal 연구진은 $\mathrm{PEO}$ 와 $\mathrm{Zn}\left(\mathrm{CF}_{3} \mathrm{SO}_{3}\right)_{2}$ 염을 여러 질량비로 제조하고 아연 |아연 대칭 셀에서 테스트했을 때, 그 중 최적값인 9:1 의 질량비로 혼합하여 만든 고체 전해질이 가장 높은 이 온 전도도 $\left(1.09 \times 10^{-6} \mathrm{~S} \mathrm{~cm}^{-1}\right)$ 를 보였다. ${ }^{47)}$ 이 값은 순 수한 $\mathrm{PEO}$ 의 이온 전도 값 $\left(3.2 \times 10^{-9} \mathrm{~S} \mathrm{~cm}^{-1}\right)$ 을 웃도는 높은 수치다. $\mathrm{PEO}$ 기반의 전해질에서 아연 염은 중요 한 역할을 하게 된다. 아연 염이 용해되었을 때 자유 이 온들이 $\mathrm{PEO}$ 매트릭스에 존재하게 되는데, 큰 음이온이 $\mathrm{PEO}$ 매트릭스에 해리된 염 매질에 적용되면 아연 자유 이온은 높은 이온 전도도와 안정성을 보여준다.

\section{2 잔탄검 기반 겔 전해질}

잔탄검은 식물 병원성 박테리아인 Xanthomonas campestris pv. campestris로부터 생산되는 천연 고분 자로서 자연에 풍부하게 존재하는 다당류이다. ${ }^{48)}$ 잔탄검
의 곁사슬(side chain)에 붙어 있는 수산화기(hydroxyl group)로 인해 물 분자를 잘 끌어오고 긴 탄소 사슬은 물과 잔탄검 사이의 상호작용을 강화한다. 분자 구조상 으로 잔탄검은 높은 이온 전도도, 높은 용해도, 높은 점 도의 특성을 가져 겔 고분자 전해질로서 잠재력을 가진 다고 알려져 있다. ${ }^{49,50)}$

Qingwen $\mathrm{Li}$ 그룹은 $\mathrm{MnO}_{2}$ /탄소 나노튜브를 양극으 로 활용한 $\mathrm{Zn}-\mathrm{MnO}_{2}$ 전지를 잔탄검, $2 \mathrm{M} \mathrm{ZnSO}_{4}, 0.1$ $\mathrm{M} \mathrm{MnSO}_{4}$ 를 혼합한 겔 전해질로 제조했다. ${ }^{51)}$ (그림 5) 이 연구에서는 잔탄검 전해질이 낮은 온도에서의 뛰어 난 안정성을 보였다. 초기의 이온 전도도는 $1.65 \times 10^{-2} \mathrm{~S}$ $\mathrm{cm}^{-1}$ 로 측정되었고, $-8{ }^{\circ} \mathrm{C}$ 에서의 이온 전도도는 $2.5 \times$ $10^{-3} \mathrm{~S} \mathrm{~cm}^{-1}$ 로 유지되었다. 심지어 $5{ }^{\circ} \mathrm{C}$ 에서 1년간 저 장한 이후의 이온 전도도는 초깃값과 유사하게 유지되 었다. 잔탄검 전해질을 사용해 제조한 전지는 $1 \mathrm{C}(0.15$ $\mathrm{mA} \mathrm{cm}{ }^{-2}$ )에서 $260 \mathrm{mAh} \mathrm{g}^{-1}$ 의 높은 방전용량을 가졌 
고, $10 \mathrm{C}$ 의 높은 충 · 방전 속도에서는 $176 \mathrm{mAh} \mathrm{g}^{-1}$ 의 방전용량을 보였다. 사이클 성능을 측정했을 때는 $1 \mathrm{C}$ 의 정전류에서 330 사이클 이상 구동시켰을 때 $282 \mathrm{mAh}$ $\mathrm{g}^{-1}$ (약 $90 \%$ 의 용량 유지)를 보였고 $5 \mathrm{C}$ 의 정전류에서 구 동시켰을 때는 150 사이클 이후에 용량 감소가 나타났 으나 이후에 1000 사이클까지 $127 \mathrm{mAh} \mathrm{g}^{-1}$ 정도로 안 정화되는 양상을 나타냈다.

또 다른 잔탄검 활용 사례로, Ying Wang과 연구진 은 나노 벨트 형태의 $\mathrm{NH}_{4} \mathrm{~V}_{3} \mathrm{O}_{8} \cdot 1.9 \mathrm{H}_{2} \mathrm{O}$ 를 양극으로 사 용하고, $12 \mathrm{M}$ 의 고농도 아연 염을 전해질로 사용했는 데, 이때 잔탄검을 추가로 사용하여 겔 형태로 전환했 다. ${ }^{52)}$ 이 연구는 영하의 온도에서도 비교적 높은 가역 용량을 가지고 사이클 특성 향상을 위해 고농도화 전략 과 잔탄검 전해질을 활용했다. 아연 염으로는 다양한 온 도에서 물에 용해가 잘 된다는 점을 활용해 $\mathrm{ZnCl}_{2}$ 를 활 용했다. 높은 염 농도로 인해 전해질의 어는점이 낮아 져 저온 구동이 가능하고 사이클 과정에서 활물질이 전 해질로 손실되는 것을 막아 사이클 특성을 향상한다. 하 지만 고농도의 $\mathrm{ZnCl}_{2}$ 수용액은 강한 산성이어서 전극 에 부식과 같은 문제를 일으킬 수 있는데 이를 해결하 기 위해 음이온성 생고분자 구조를 가져 내염성(salttolerance)이 좋은 잔탄검을 활용해 전해질을 겔 형태로 전환하는 방법을 이용했다. $20{ }^{\circ} \mathrm{C}$ 과 $-20{ }^{\circ} \mathrm{C}$ 에서 이온 전도 값을 측정해 본 결과 $20{ }^{\circ} \mathrm{C}$ 에서는 $13.8 \mathrm{mS} \mathrm{cm}$-1 로 다른 전해질(젤라틴, $\mathrm{PEO}, \operatorname{poly}(\varepsilon$-carpolactone), polyvinylpyridine 등)보다 높은 값을 나타냈고, -20 ${ }^{\circ} \mathrm{C}$ 에서는 $5 \mathrm{mS} \mathrm{cm}$ 로 측정되었다. ${ }^{53-56)}$ 제조된 전지는 가역 용량과 충 · 방전 속도에 대한 성능 테스트도 진행 되었고, $0.2 \mathrm{~A} \mathrm{~g}^{-1}$ 의 전류밀도로 충전되었을 때 $20{ }^{\circ} \mathrm{C}$ 에 서 $283 \mathrm{mAh} \mathrm{g}^{-1}, 0{ }^{\circ} \mathrm{C}$ 에서 $215 \mathrm{mAh} \mathrm{g}^{-1},-20{ }^{\circ} \mathrm{C}$ 에서 $119 \mathrm{mAh} \mathrm{g}^{-1}$ 의 방전용량을 보였다. 또한, $1.5 \mathrm{~A} \mathrm{~g}^{-1}$ 의 전류밀도로 800 사이클 이후에도 $20{ }^{\circ} \mathrm{C}$ 에서 $90.3 \%, 0$ ${ }^{\circ} \mathrm{C}$ 에서 $90.7 \%$ 의 용량을 유지했다. $-20{ }^{\circ} \mathrm{C}$ 에서는 $0.5 \mathrm{~A}$ $\mathrm{g}^{-1}$ 로 구동되었을 때 450 사이클 이후에도 초기 용량의 $83 \%$ 를 유지하는 높은 사이클 성능을 보였다. ESS의 저 온에서의 안정성 확보를 위한 측면, 유연한 특성을 활용 한 웨어러블 기기에 적용할 수 있다는 측면에 있어서 의
미 있는 결과라고 할 수 있다.

잔탄검은 내염성이 높아서 이온 전도도가 높지만, 기 계적 강도가 낮은 한계가 있다. 또, 겔 전해질의 늘어 나는 특성으로 인해 인장력이 가해졌을 때 전극과 집전 체 사이의 접합이 떨어져 용량 감소를 초래하기도 한 다. ${ }^{57)}$ 이러한 문제점을 해결하기 위해서는 탄소 물질이 나 고분자 물질을 집전체에 코팅해 전극과 집전체 계면 사이 접착력을 향상하는 방법 등이 고안되어야 할 필요 가 있다

\section{3 젤라틴 기반 겔 전해질}

젤라틴은 변성 콜라겐으로부터 추출되어 주로 프롤 린, 하이드록시프롤린, 글리신으로 구성된 천연 고분자 중 하나로서 분자 가지에 많은 친수성 작용기가 달려있 다. 따라서, 고분자 매트릭스에서 물 분자를 잘 함유해 높은 이온 전도도를 가진다. ${ }^{58)}$ 일반적으로, 젤라틴은 가 열 조건에서 수계 전해질에 쉽게 용해되고, 이후에 냉각 과정에서 나선형 구조로 변하면서 고체 네트워크를 형 성하는데 이 고체 네트워크는 전극에 코팅되어 높은 유 연성을 가질 수 있다. ${ }^{59)}$

젤라틴을 전해질로 활용한 연구로, $\mathrm{Yu} \mathrm{Liu}$ 그룹은 $0.5 \mathrm{M}$ 의 $\mathrm{Li}_{2} \mathrm{SO}_{4}$ 와 $0.5 \mathrm{M}$ 의 $\mathrm{ZnSO}_{4}$ 를 젤라틴 전해질 과 혼합해 연구를 수행했다. ${ }^{60)}$ 이렇게 제조된 전해질 은 $6.15 \times 10^{-3} \mathrm{~S} \mathrm{~cm}^{-1}$ 의 높은 이온 전도 값을 보였고, $5{ }^{\circ} \mathrm{C}$ 에서의 전해질의 압축 강도는 $25{ }^{\circ} \mathrm{C}$ 에서의 압축 강 도보다 2 배 높은 값을 나타냈다. 사이클 안정성을 확인 하기 위해 아연|아연 대칭 전지에서 젤라틴 기반 전해 질을 사용했을 때는 자가부식 현상과 수지상 형성을 거 의 보이지 않았다. 또, 젤라틴의 친수성으로 인해 물을 잘 함유해 물의 증발도 억제할 수 있었다. $25 \mathrm{~mA} \mathrm{~g}^{-1}$ 의 전류밀도에서 100 사이클 이후의 용량 유지는 $90 \%$ 에 이르렀다. 또 다른 연구로, Kevin Huang 연구진 은 젤라틴의 약한 기계적 강도의 단점을 보완하기 위 해, 젤라틴과 알긴산 나트륨이 이중 가교 결합한 $3 \mathrm{D}$ 구조의 하이드로겔 전해질을 개발했다. ${ }^{61)}$ (그림 6) 하 이드로겔 전해질을 제조하기 위해서는 먼저 젤라틴을 glutaraldehyde와 먼저 가교결합 하는데 이때 젤라틴 
(a)
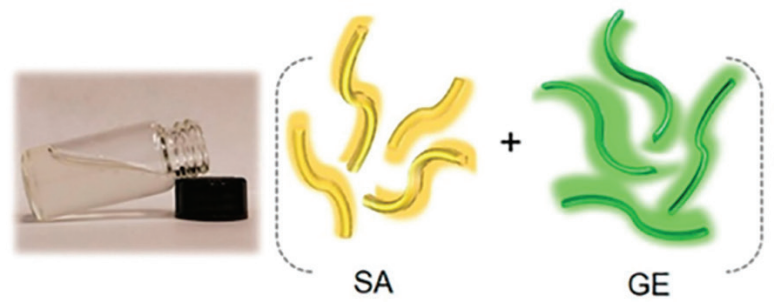

Glutaraldehyde

1
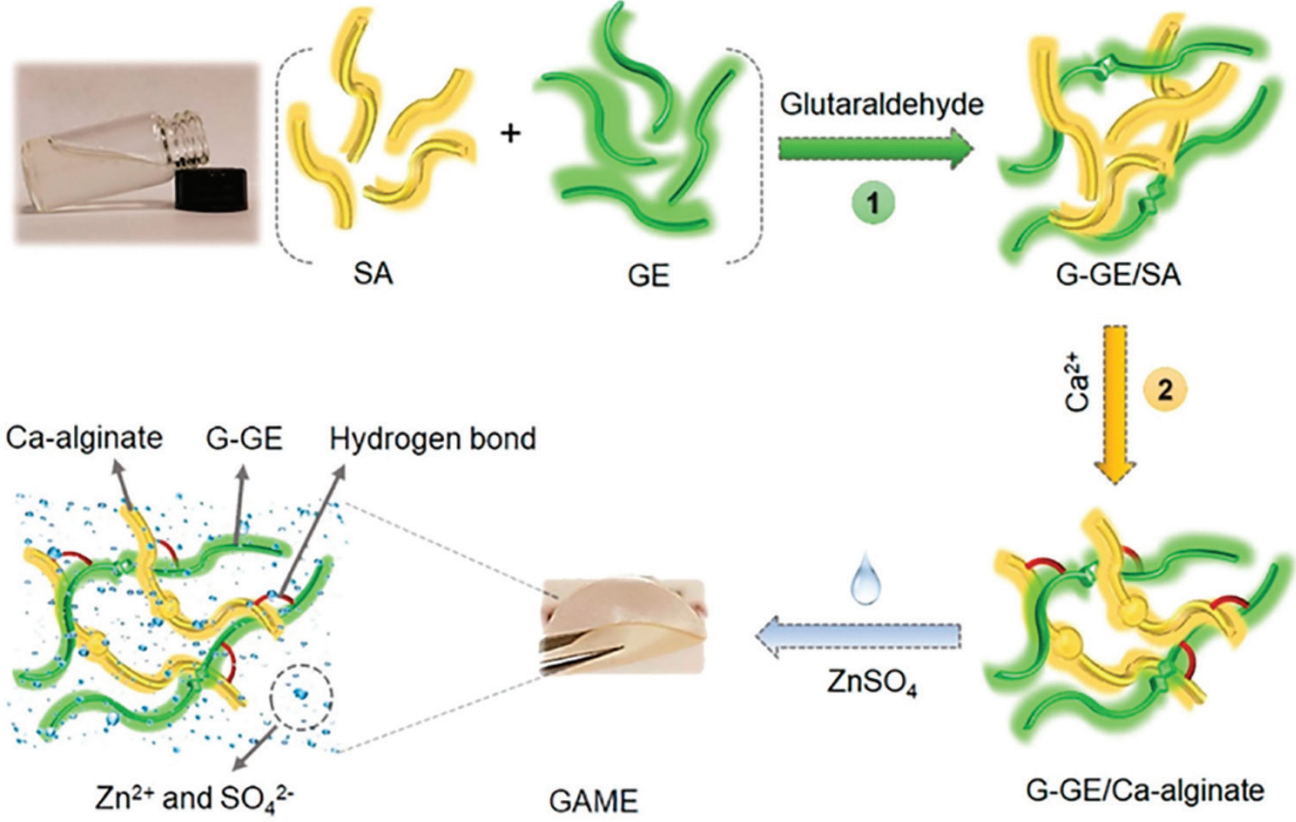

GAME

G-GE/Ca-alginate
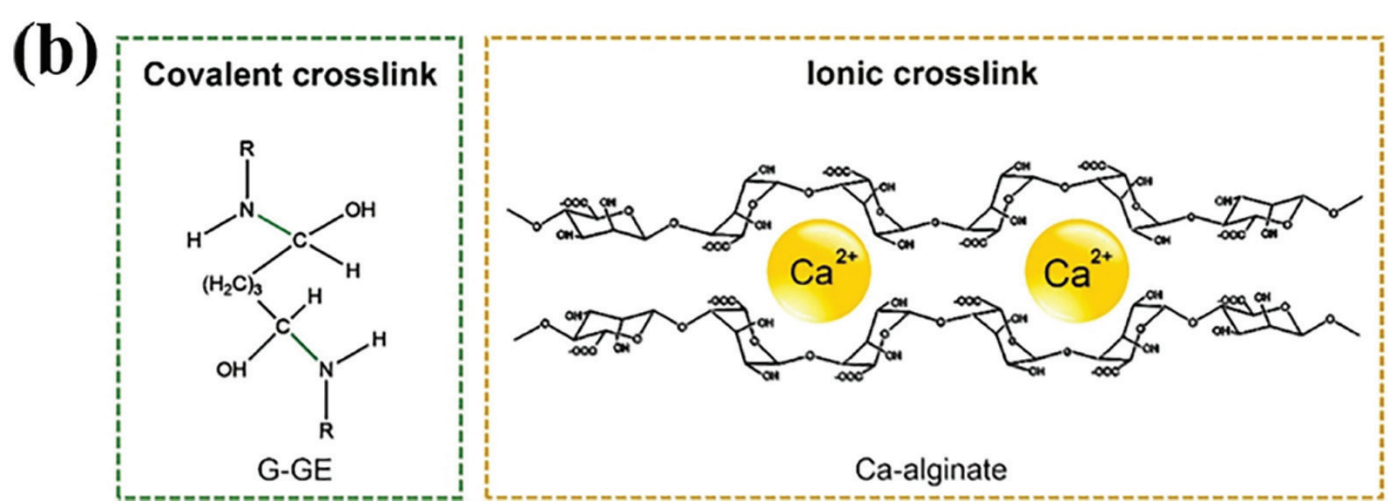

Figure 6. (a) Schematic of the overall process to make gelatin- and alginate-based membrane electrolyte (GAME) (b) Crosslinked polymers of gelatin (GE) cross-link with glutaraldehyde and Ca-alginate (sodium alginate (SA) cross-link with $\mathrm{CaCl}_{2}$ ). Reproduced from Lu et al. ACS Appl. Energy Mater. 2019;2:6904-6910, with permission of American Chemical Society [61].

의 아민기와 glutaraldehyde가 강한 상호작용으로 공유 결합하여 기계적 강도를 높인다. 다음으로 알긴산 나트 륨과 $\mathrm{CaCl}_{2}$ 사이의 이온 가교결합을 통해 형성된 알긴산 나트륨의 블록이 강한 미세구조를 형성해서 전해질 흡 수 이후에 아연 이온 운송을 위한 발판을 제공한다. 이 후에, $\mathrm{ZnSO}_{4}$ 용액을 적시면 유연성 전해질로 변하게 된 다. 이러한 과정을 통해 아연 이온 수송을 가속하고 기 계적 특성을 향상할 수 있다. 이 전해질을 아연 금속 음 극, $\mathrm{V}_{2} \mathrm{O}_{5} / \mathrm{CNT}$ 나노 복합체 양극으로 적용한 완전지를
제조해서 가역 용량을 확인해 본 결과, $2 \mathrm{~A} \mathrm{~g}^{-1}$ 으로 구 동했을 때 200 사이클 이후에 $212 \mathrm{mAh} \mathrm{g}^{-1}$ 를 나타내며 초기 용량의 $85 \%$ 를 유지하였고 400 사이클 이후에는 $79 \%$ 를 유지하였다.

젤라틴 기반 전해질은 젤라틴의 친수성으로 인해 이 온 수송이 원활해 높은 이온 전도도의 장점이 있지만 낮 은 기계적 강도로 인해 단독으로 사용되기 어렵다. 따라 서 가교결합, 강도가 높은 고분자와의 블렌딩, 또는 실 리카, 알루미나와 같은 무기물질과의 복합화를 통해 기 

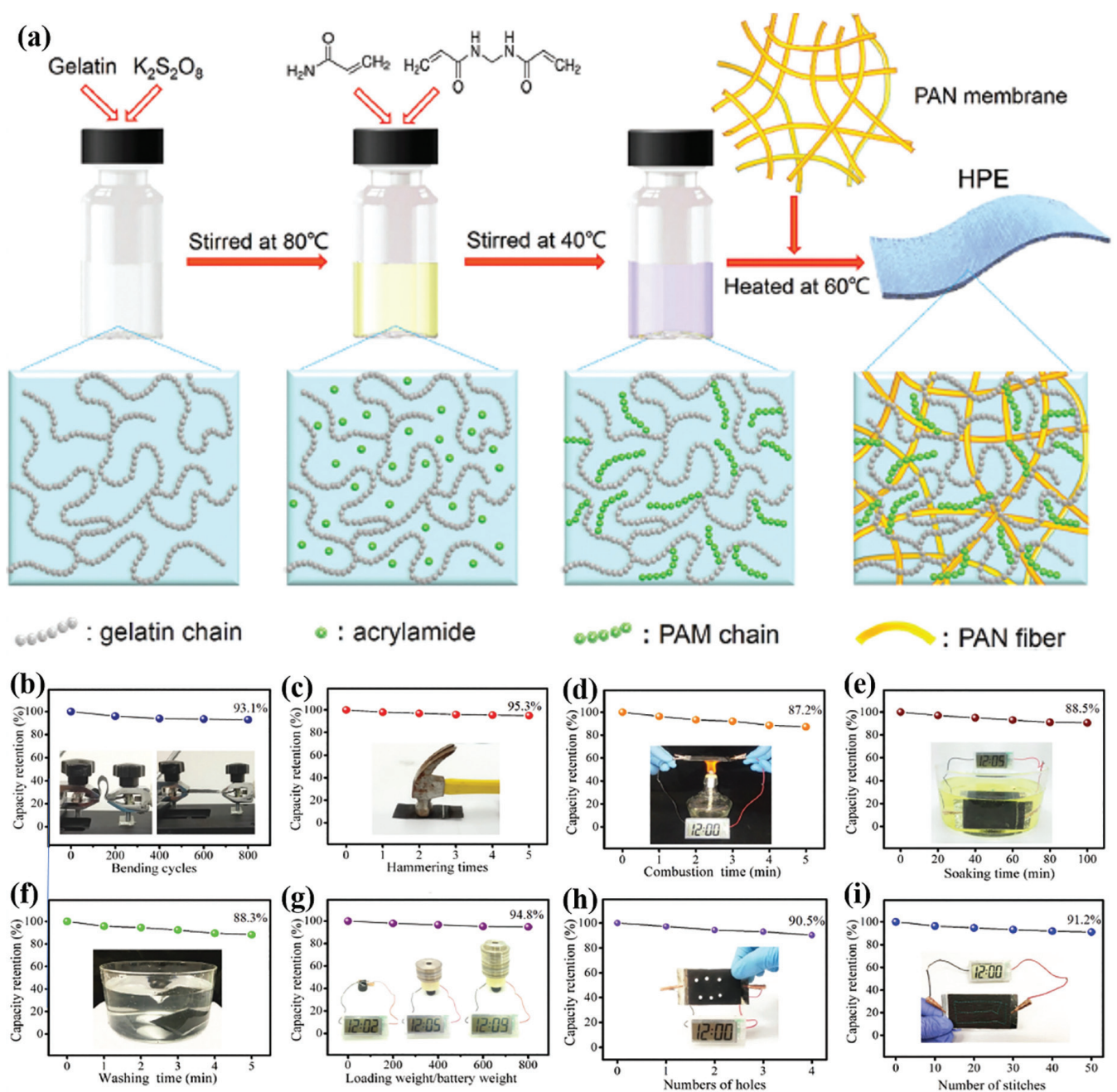

Figure 7. (a) Schematic of the synthesis route to the hydrogel polymer electrolyte (HPE). Electrochemical performance of the solidstate rechargeable ZIB in different destructive tests. (b) Bending test. (c) Hammering test. (d) Combustion test. (e) Soaking test. (f) Washing test. (g) Weight loading test. (h) Drilling test. (i) Sewing test. Reproduced from Li et al. Energy Environ. Sci. 2018;11:941-951, with permission of Royal Society of Chemistry [65].

계적 강도를 높이는 방법이 고안되어야 한다.

\subsection{PAM 기반 겔 전해질}

$\mathrm{PAM}$ 은 분자 구조상 많은 친수성 작용기와 아마이 드 작용기 $\left(-\mathrm{CONH}_{2}\right)$ 로 인해 물 분자를 잘 수용하고 이 온 수송을 위한 네트워크 구조를 가지기에 유리해 다 양한 이온의 전도성 전해질로 사용되었다. ${ }^{62-64)}$ 하지 만, 순수한 PAM으로만은 강한 기계적 특성을 구현하기 가 어려워 화학적 가교결합과 같은 방법으로 기계적 특
성을 강화할 필요가 있다. $\mathrm{PAM}$ 은 acrylamide 단량체 (monomer)와 개시체(initiator), 가교제(cross-linker) 를 활용해 가교할 수 있는데, PAM의 고분자 사슬의 작 용기들과 가교제의 강한 공유결합을 통해 형성된다.

Chunyi Zhi와 연구진은 PAM과 젤라틴 기반 층상 고 분자 전해질을 $\alpha-\mathrm{MnO}_{2}$ 나노 로드/탄소나노튜브를 양 극으로 활용한 전지에 사용했다. ${ }^{65)}$ (그림 7) 이 연구에서 는 PAM을 polyacrylonitrile(PAN) 섬유막 내에 채워진 젤라틴 사슬에 접합시켜 기계적 강도와 이온 전도도를 
강화했다. $3 \mathrm{D}$ 구조의 기공성 구조와 물 함유 능력 덕분 에 굉장히 높은 상온 이온 전도도 $\left(1.76 \times 10^{-2} \mathrm{~S} \mathrm{~cm}^{-1}\right)$ 를 보여줬다. 이 전해질로 제조된 완전지는 $2772 \mathrm{~mA} \mathrm{~g}^{-1}$ 의 전류밀도에서 $6.18 \mathrm{mWh} \mathrm{cm}$ 의 높은 면적당 에너지밀 도와 $148.2 \mathrm{~mW} \mathrm{~cm}$ 의 파워밀도를 나타냈고 $61.6 \mathrm{~mA}$ $\mathrm{g}^{-1}$ 에서 $306 \mathrm{mAh} \mathrm{g}^{-1}$ 의 좋은 질량 당 용량을 보여줬다. 사이클 성능 또한 $2772 \mathrm{~mA} \mathrm{~g}^{-1}$ 의 전류밀도에서 1000 사이클 이후에도 용량의 $97 \%$ 를 보존해 높은 성능을 보 였다. 또한, 뛰어난 안정성과 함께 유연성을 가져 웨어 러블 장비에 적용할 수 있고, 절단, 구부러짐, 충격, 화 염, 세척 등의 외부의 극한 조건에서도 구동하는 전지를 선보였다. (그림 $7 \mathrm{~b}-\mathrm{i}$ )

$\mathrm{PAM}$ 겔 전해질을 활용한 다른 연구로, Rui $\mathrm{Li}$ 그룹 은 $3 \mathrm{M}$ 의 $\mathrm{Zn}\left(\mathrm{CF}_{3} \mathrm{SO}_{3}\right)_{2}$ 을 함유하는 $\mathrm{PAM}$ 전해질을 고 안했다. ${ }^{66)} 3 \mathrm{M}$ 의 염이 녹아있는 고분자 전해질을 활용 함으로써, 고농도화 전략의 효과와 더불어 겔 전해질의 장점까지 더했다. 이 전해질을 $3 \mathrm{M}$ 의 $\mathrm{Zn}\left(\mathrm{CF}_{3} \mathrm{SO}_{3}\right)_{2}$ 수 용액 전해질과 $1 \mathrm{M}$ 의 $\mathrm{ZnSO}_{4}$ 전해질에 각각 비교하면서 수지상 형성 억제, 낮은 과전압, 아연 금속의 부식문제 해결 등의 장점을 내세웠다. 이 연구에서 사용된 양극재 는 층상구조의 $\mathrm{Mg}_{0.1} \mathrm{~V}_{2} \mathrm{O}_{5} \cdot \mathrm{H}_{2} \mathrm{O}$ 나노 벨트로, $5.0 \mathrm{~A} \mathrm{~g}^{-1}$ 의 전류밀도에서 $358 \mathrm{mAh} \mathrm{g}^{-1}$ 의 높은 용량과 충 · 방전 속도를 자랑한다. PAM 기반 고농도 겔 전해질 덕분에 같은 전류밀도에서 3000 사이클 이후에 $95 \%$ 의 용량을 유지하는 장기간 사이클 특성을 보여줬다. 그뿐만 아니 라, $-30{ }^{\circ} \mathrm{C}$ 에서 $274 \mathrm{mAh} \mathrm{g}^{-1}, 80{ }^{\circ} \mathrm{C}$ 에서 $501 \mathrm{mAh} \mathrm{g}^{-1}$ 을 보이면서 100 사이클 이후에도 거의 $100 \%$ 용량 유지 가 되는 극한 온도 조건에서의 구동 능력도 보였다. 각 온도에서의 이온 전도도를 측정하였는데, 이는 $20{ }^{\circ} \mathrm{C}$ 에 서 $27.1 \mathrm{mS} \mathrm{cm} \mathrm{cm}^{-1}, 80{ }^{\circ} \mathrm{C}$ 에서 $73.8 \mathrm{mS} \mathrm{cm}{ }^{-1},-30{ }^{\circ} \mathrm{C}$ 에 서 $1.9 \mathrm{mS} \mathrm{cm}$ 로 나타나며 극한 온도 조건에서도 양호 한 이온 전도도를보였다.

위의 두 연구 외에도 PAM 전해질은 가교 결합한 $\mathrm{PAM}$ 겔 전해질을 기능성 실(yarn) 전지에 적용한 연 구, ${ }^{67)}$ 녹말과 $\mathrm{PAM}$ 을 조합해 높은 아연 이온 전도도를 얻어 아연 $/ \mathrm{MoS}_{2}$ 나노시트 전지에 적용한 연구, ${ }^{68)}$ 바인 더가 없는 층상 $\mathrm{VS}_{2}$ 전극을 통해 상용화 단계의 전극 로
딩양을 갖춘 연구 ${ }^{69}$ 등에 다양하게 활용되었다. 대부분 의 연구에서 높은 이온 전도를 보이면서 안정성, 유연 성, 장수명 특성 등의 장점을 보였다. $\mathrm{PAM}$ 을 가교결합 시켜 기계적 강도를 보완해 활용했듯이 다른 고분자 또 한 가교결합을 통해 안정성을 높이는 방향으로 활용가 치가 높아질 수 있다.

\subsection{PVDF 기반 겔 전해질}

$\mathrm{PVDF}$ 기반 전해질은 $\mathrm{CF}_{2}$ 기의 전자를 강하게 당기 는 성질과 높은 유전상수 $(\varepsilon=8.4)$ 로 인해 금속염의 이 온화를 돕고, 이온 전도도를 향상해 음극의 안정성 을 높이는 역할을 한다. ${ }^{70)}$ 하지만, $\mathrm{PEO}$ 기반 겔 전 해질과 유사하게 기계적 강도가 낮은 한계가 있다. Sampath 그룹은 PVDF와 propylene carbonate(PC), ethylene carbonate(EC), zinc trifluoromethane sulfonate(ZnTr)를 혼합하여 겔 전해질을 만들어 아 연 $\mid \gamma-\mathrm{MnO}_{2}$ 전지를 제조하였다. $27^{\circ} \mathrm{C}$ 에서 질량 비 를 1:2:2:0.6 (PVDF/PC/EC/ZnTr)로 했을 때 가 장 높은 $3.94 \times 10^{-3} \mathrm{~S} \mathrm{~cm}^{-1}$ 의 이온 전도 값을 나 타냈다. 이온 전도도를 더 향상하기 위해 올리고머 poly(ethylene glycol) dimethyl ether(PEGDME)를 poly(vinylidenefluoride-co-hexafluoropropylen) (PVDF-HFP)에 첨가했는데, 이를 통해 아연 염을 용매 화시키고 PVDF-HFP를 안정화하는 역할을 했다.

$\mathrm{PVDF}$ 를 활용한 또 다른 방법으로 이온성 액체 를 PVDF-HFP에 첨가하는 방법이 있는데 이는 아 연 염을 완전히 용해하고 $\mathrm{PVDF}-\mathrm{HFP}$ 고분자와 잘 혼합되게 한다. $\mathrm{Xu}$ 와 연구진은 $\mathrm{PVDF}-\mathrm{HFP}$ 와 zinc triflate $\left(\mathrm{Zn}(\mathrm{Tf})_{2}\right)$, 1-ethyl-3-methylimidazolium trifluoromethanesulfonate (EMITf) 또는 $\mathrm{Zn}(\mathrm{TFSI})_{2}$, 1-ethyl-3-methylimidzoliumbis(trifluoromethane sulfonyl)imide (EMITFSI)를 혼합해 겔 전해질을 제작 했다. ${ }^{71)}$ 이 전해질은 상온에서 $10^{-3} \mathrm{~S} \mathrm{~cm}^{-1}$ 의 이온 전도 도를 보여줬다. 이온성 액체의 첨가에 따라 PVDF 사슬 과 아연 이온의 상호작용이 약해지고 이온 이동이 활발 해져 높은 이온 전도도를 얻을 수 있다. 기존 무기물 첨 가제보다 이온성 액체는 휘발성이 없고 $\mathrm{PVDF}$ 와 쉽 
(a)

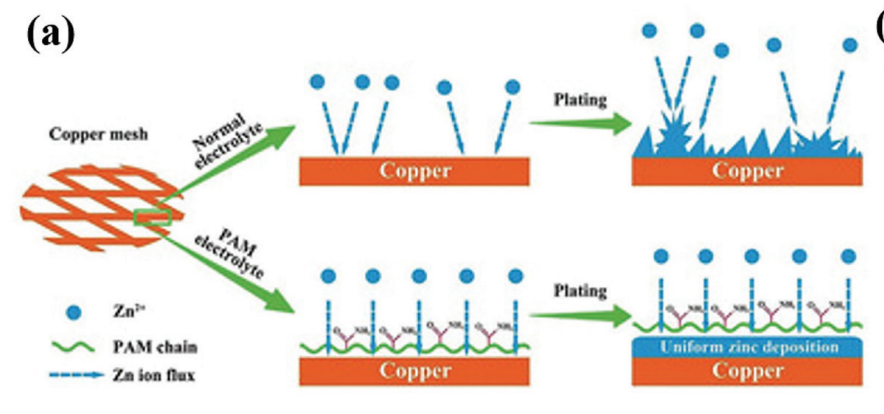

(b)
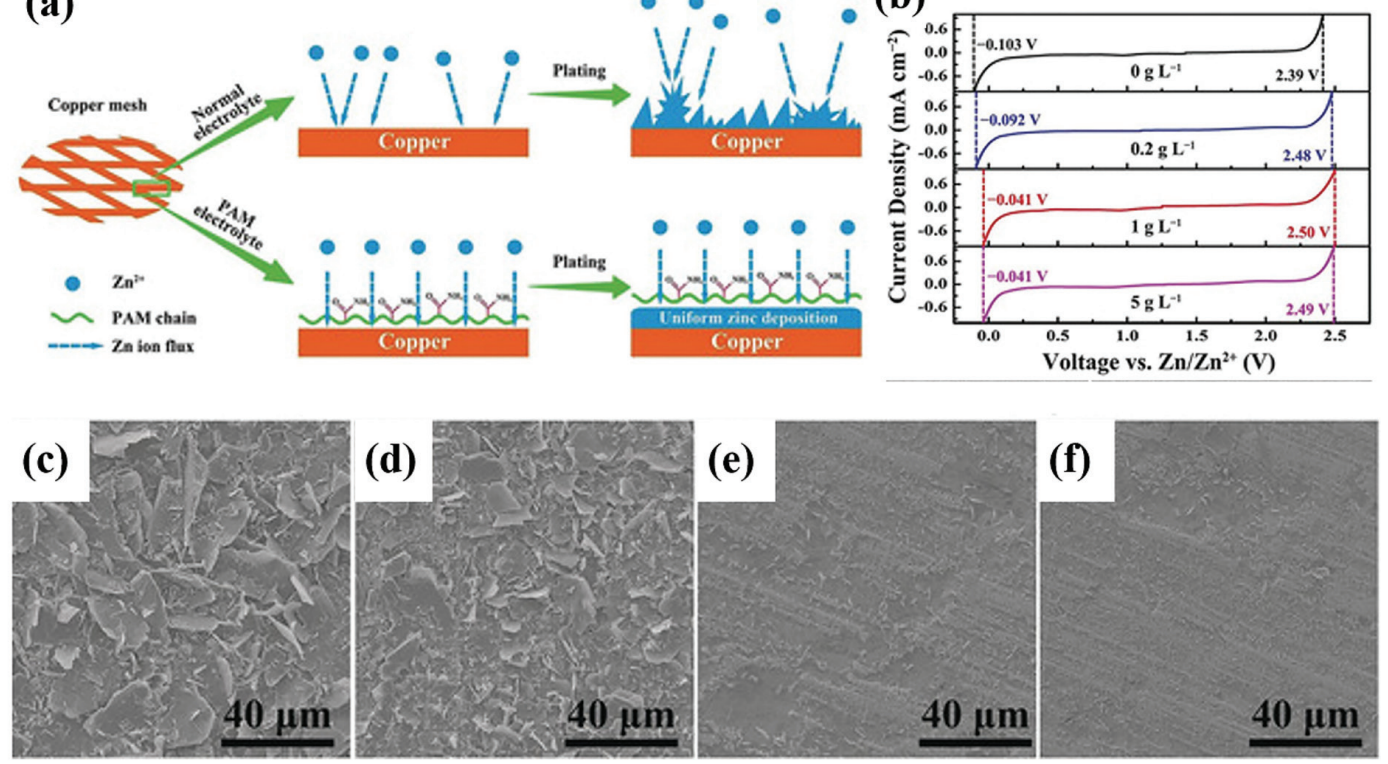

(e)

(f)

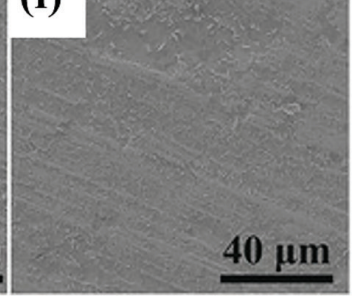

Figure 8. (a) Schematic illustration of zinc deposition on the copper mesh in normal and PAM-added electrolytes. (b) Electrochemical windows of the electrolytes with difference PAM concentrations. (c-f) The surface morphologies of commercial zinc foil after immersion for 7 days in the electrolyte with the PAM concentration of $0,0.2,1$ and $5 \mathrm{~g} \mathrm{~L}^{-1}$, respectively. Reproduced from Zhang et al. Angew. Chem. Int. Ed. 2019;58:15841-15847, with permission of John Wiley and Sons [79].

게 융합해 아연 이온 수송을 위한 전해질로 고려될 수 있다.

\section{4. 첨가제}

전해질에 사용하는 첨가제는 균일하지 않은 아연이 온 증착을 균일하게 유도해 수지상 형성을 억제해 전지 의 사이클 특성을 향상하거나, 작동 전압 영역대를 넓혀 더 높은 에너지밀도를 갖게 하는 전략으로 사용된다. ${ }^{72)}$ 첨가제들은 주로 유기물이나 금속이온으로 구성되어 있 는데, 전류 분포를 조절하고 아연 이온의 평면적 확산을 효과적으로 제한하기 때문에 수지상 형성을 억제할 수 있다. ${ }^{73)}$

니켈 $(\mathrm{Ni})$ 과 같은 금속이온 첨가제는 아연과 반응해 합 금을 형성하여 수지상 형성을 고르게 만들어 수지상 형 성으로부터 일어나는 문제를 예방하기도 한다. Frank Endres 연구진은 zinc triflate $\left(\mathrm{Ni}(\mathrm{TfO})_{2}\right)$ 를 포함하는 이온성 액체를 전해질 첨가제로 활용해 아연-니켈 합금
의 형성을 유도해 음극의 계면에서 발생하는 아연 이온 의 결정핵 생성을 고르게 유도한 연구를 수행했다. ${ }^{74)}$ 이 외에도 아연보다 높은 전위를 가지는 $\mathrm{Bi}^{3+}, \mathrm{Pd}^{2+}, \mathrm{Nd}^{3+}$ 와 같은 금속 이온들은 아연보다 먼저 환원되어서 아연 증착의 기질로서 작용하고 전극의 전도성을 높여줌으로 써 아연 증착을 고르게 한다. ${ }^{75-77)}$ 하지만 $\mathrm{Na}_{2} \mathrm{SO}_{4}$ 와 같 은 금속염들은 산화 환원 반응에 직접적으로는 관여하 지 않지만, 아연 표면에 흡착되어 정전기적 반발을 줄여 수지상 형성을 억제하고 아연 금속의 고르지 않은 용해 를 예방하기도 한다. ${ }^{78)}$

유기물 첨가제 중 하나로서 PAM이 수지상 형성을 억 제하는 데 기여한 연구가 있다. Haiyan Wang과 연구 진은 구리-아연 고용체(solid solution)를 망사구조의 구리 집전체에 접합시키고 $\mathrm{PAM}$ 을 첨가제로 활용해 수 지상 형성을 억제한 3 차원 구조의 음극 설계를 고안했 다. ${ }^{79)}$ 구리-아연 고용체는 아연의 증착 과정에서 결정 핵 생성이 발생하는 위치를 지정하는 역할을 하고 PAM 은 전극 제조과정과 충 - 방전 과정에서 모두 아연 증 
착이 균일하도록 유도하는 안내 중재자 역할을 한다. $\mathrm{PAM}$ 은 먼저 구리 표면에 흡수되고 아연 이온은 PAM 사슬의 아실기(acyl groups)에 의해 표면을 이동할 수 있다. PAM으로 표면처리를 함으로써 생긴 고른 전기장 과 전하 분포 때문에 아연이온은 증착 과정에서 균일하 고 부드러운 모양으로 성장한다. 이 연구에서는 $\mathrm{PAM}$ 의 농도를 $0 \mathrm{~g} \mathrm{~L}^{-1}, 0.2 \mathrm{~g} \mathrm{~L}^{-1}, 1 \mathrm{~g} \mathrm{~L}^{-1}, 5 \mathrm{~g} \mathrm{~L}^{-1}$ 로 각각 다르게 설정하여 작동 전압 영역대와 아연 금속의 표면 분석도 진행했다. 아연 도금의 전압은 $-0.103 \mathrm{~V}$ 에서 $-0.041 \mathrm{~V}$ 로 변동되었는데 이는 아연 도금 과정에서의 $\mathrm{PAM}$ 의 활성에 기인한다고 설명한다. 또, 산소발생반응 전압이 $0.1 \mathrm{~V}$ 정도 향상되면서 작동 전압 영역을 확장하 는 데 기여했다. 아연 호일을 $\mathrm{PAM}$ 이 첨가된 전해질에 7일간 담가 놨을 때, $\mathrm{PAM}$ 의 농도가 증가할수록 표면이 안정한 모습을 보였다. 이는 PAM이 아연 표면에 흡수 되어 용해된 $\mathrm{O}_{2}$ 와 약산성의 용액으로부터 부식되는 것 을 방지해준다.

유기물을 활용해 수지상 형성을 억제한 다른 연구로 Xudong Wang 그룹은 2 vol\%의 diethyl ether $\left(\mathrm{Et}_{2} \mathrm{O}\right)$ 를 첨가제로 활용해 사이클 성능을 높인 연구를 수행했 다. ${ }^{80)}$ 아연 이온 증착 과정에서 양극화된 소량의 $\mathrm{Et}_{2} \mathrm{O}$ 는 아연 음극 표면의 뾰족한 부분으로 흡착된다. $\mathrm{Et}_{2} \mathrm{O}$ 가 없는 경우 이 부분에 아연 이온 증착이 계속해서 이루어 지면서 수지상 형성을 초래한다. 하지만 흡착된 $\mathrm{Et}_{2} \mathrm{O}$ 가 이를 억제하여 음극 안정성을 갖추도록 하는 역할을 했 다. $\mathrm{Et}_{2} \mathrm{O}$ 를 첨가제로 활용해 $\mathrm{MnO}_{2}$ 양극과 전지를 제작 했을 때, $50 \mathrm{~mA} \mathrm{~g}^{-1}$ 에서 첫 번째 사이클의 쿨롱 효율은 $95.6 \%$ 로 나타났고, $5 \mathrm{~A} \mathrm{~g}^{-1}$ 에서 용량은 $115.9 \mathrm{mAh} \mathrm{g}^{-1}$ 으로 나타났으며, 4000 사이클 이후에도 초기 용량의 $97.7 \%$ 를 유지하면서 높은 충 - 방전 속도와 사이클 성능 을 나타냈다.

고농도화 전략과 유사하게 전해질의 작동 전압 영 역을 넓히는 방법으로 dimethyl sulfoxide(DMSO)를 유기물 첨가제로 활용한 사례가 있다. ${ }^{81)}$ 이 연구에서 는 $1.6 \mathrm{M}$ 의 $\mathrm{ZnCl}_{2}-\mathrm{H}_{2} \mathrm{O}$ 용액 $\left(\mathrm{ZnCl}_{2}: \mathrm{H}_{2} \mathrm{O}=1: 34\right.$ 몰 비) 에 $\mathrm{DMSO}$ 를 넣어 $1.3 \mathrm{M}$ 의 $\mathrm{ZnCl}_{2} / \mathrm{H}_{2} \mathrm{O}-\mathrm{DMSO}\left(\mathrm{H}_{2} \mathrm{O} /\right.$ $\mathrm{DMSO}=4.3: 1$ 부피 비)를 형성하도록 함으로써 아
연 이온의 용해 껍질을 채우고 있는 물 분자를 대체했 다. 따라서 아연 이온이 $\mathrm{DMSO}$ 로 먼저 용해되고, 추 가로 $\mathrm{H}_{2} \mathrm{O}-\mathrm{DMSO}$ 의 강한 상호작용이 물 분자의 분해 를 막는다. 게다가 용해된 $\mathrm{DMSO}$ 의 환원에 의한 분해 는 $\mathrm{Zn}_{12}\left(\mathrm{SO}_{4}\right)_{3} \mathrm{Cl}_{3}(\mathrm{OH})_{15} \cdot 5 \mathrm{H}_{2} \mathrm{O}, \mathrm{ZnSO}_{3}, \mathrm{ZnS}$ 가 풍부 한 고체/전해질 계면 상(solid electrolyte interphase, $\mathrm{SEI}$ 층을 형성해 수지상 형성도 억제한다. DMSO 첨가 제를 넣고 $\mathrm{Zn} \mid \mathrm{MnO}_{2}$ 반쪽 전지 테스트를 했을 때, 환원 이 $1.15 \mathrm{~V}$ 로 나타나면서 첨가제를 넣지 않았을 때의 값 (1.22 V)보다 낮게 측정되었다. $\mathrm{Zn} \mid \mathrm{MnO}_{2}$ 완전지는 0.3 $\mathrm{C}$ 로 충전되었을 때 $212 \mathrm{Wh} \mathrm{kg}^{-1}$ 의 높은 에너지밀도를 보였고, $8 \mathrm{C}$ 에서 충 · 방전 되었을 때 첨가제를 넣으면 500 사이클 동안 $\sim 150.3 \mathrm{mAh} \mathrm{g}^{-1}$ 의 용량을 보이며 초 기 용량의 $95.3 \%$ 가 유지되었으나 첨가제를 넣지 않으면 150 사이클 내에 용량이 급격하게 감소했다.

\section{5. 결론}

$\mathrm{AZIB}$ 는 $\mathrm{ESS}$ 로 적용하기 위해 $\mathrm{LIB}$ 를 대체하는 전지 로 여겨지면서 수많은 연구가 수행되고 있다. 본 총설에 서는 $\mathrm{AZIB}$ 를 구성하는 중요한 요소인 전해질에 초점을 맞춘 연구들이 소개되었다. AZIB에서 주로 문제로 여 겨지는 수지상 형성 및 성장, 좁은 작동 전압 영역대, 제 한된 구동 온도 조건 등과 같은 문제들을 해결하기 위해 고농도화 전략, 겔 전해질의 사용, 첨가제의 사용과 같 은 전략들이 주로 연구되었다. 이로 인해 장기간의 사이 클 구동이 가능해질 뿐만 아니라 높은 에너지밀도를 얻 는 성과를 얻을 수 있었는데, 그 과정에서 전해질의 역 할이 중요하게 다뤄졌다. 그러나 큰 규모에 적용되기에 는 원가, 제조 공정 등의 요소를 고려해야 하므로 일부 연구결과가 실제 산업에 적용되기에는 어려움이 있다. 특히 고농도화 전략에서는 고농도화에 따른 점도 향상 문제가 발생할 수 있으며, 많은 양의 전해질이 투입됨 에 따라 단가가 치솟는 한계점이 있다. 유연성, 기계적 안정성의 장점이 있는 겔 전해질은 액체 전해질보다 이 온 전도도가 낮아 아직은 유연 전지와 같은 특수 시스템 에만 국한되는 경향이 있다. 향후, 차세대 에너지 저장 
장치로서 AZIB가 사용되기 위해서는 AZIB의 특장점인 빠른 충 - 방전 속도를 유지하고, 고에너지 밀도를 위해 높은 전압을 갖는 양극재의 개발과 더불어 양극재와 좋 은 호환성을 가지는 안정적인 다기능성 전해질의 개발 이 필요하다.

\section{REFERENCES}

1. H. Li, L. McRae, C. J. Firby and A. Y. Elezzabi, "Rechargeable Aqueous Electrochromic Batteries Utilizing Ti-Substituted Tungsten Molybdenum Oxide Based $\mathrm{Zn}^{2+}$ Ion Intercalation Cathodes," Adv. Mater., 31 [15] 1807065 (2019).

2. Y. Liang, H. Dong, D. Aurbach and Y. Yao, "Current Status and Future Directions of Multivalent Metal-Ion Batteries," Nat. Energy, 5 [9] 646-656 (2020).

3. D. Kundu, S. Hosseini Vajargah, L. Wan, B. Adams, D. Prendergast and L. F. Nazar, "Aqueous vs. Nonaqueous Zn-Ion Batteries: Consequences of the Desolvation Penalty at The Interface," Energy Environ. Sci., 11 [4] 881-892 (2018).

4. X. Fan, L. Chen, O. Borodin, X. Ji, J. Chen, S. Hou, T. Deng, J. Zheng, C. Yang, S.-C. Liou, K. Amine, K. Xu and C. Wang, "Non-Flammable Electrolyte Enables Li-Metal Batteries with Aggressive Cathode Chemistries," Nat. Nanotechnol., 13 [8] 715-722 (2018).

5. L. Chen, Q. An and L. Mai, "Recent Advances and Prospects of Cathode Materials for Rechargeable Aqueous Zinc-Ion Batteries," Adv. Mater. Interfaces, 6 [17] 1900387 (2019).

6. J. Zhou, L. Shan, Z. Wu, X. Guo, G. Fang and S. Liang, "Investigation of $\mathrm{V}_{2} \mathrm{O}_{5}$ As a Low-Cost Rechargeable Aqueous Zinc Ion Battery Cathode," ChemComm, $\mathbf{5 4}$ [35] 4457-4460 (2018).

7. T. Zhang, Y. Tang, S. Guo, X. Cao, A. Pan, G. Fang, J. Zhou and S. Liang, "Fundamentals and Perspectives in Developing Zinc-Ion Battery Electrolytes: a Comprehensive Review," Energy Environ. Sci., 13 [12] 4625-4665 (2020).

8. Y. Jin, K. S. Han, Y. Shao, M. L. Sushko, J. Xiao, H. Pan and J. Liu, "Stabilizing Zinc Anode Reactions by Polyethylene Oxide Polymer in Mild Aqueous Electrolytes," Adv. Funct. Mater., 30 [43] 2003932 (2020).
9. H. Qiu, X. Du, J. Zhao, Y. Wang, J. Ju, Z. Chen, Z. Hu, D. Yan, X. Zhou and G. Cui, "Zinc Anode-Compatible in-situ Solid Electrolyte Interphase Via Cation solvation Modulation," Nat. Commun., 10 [1] 5374 (2019).

10. Q. Zhang, J. Luan, X. Huang, Q. Wang, D. Sun, Y. Tang, X. Ji and H. Wang, "Revealing the Role of Crystal Orientation of Protective Layers for stable Zinc Anode," Nat. Commun., 11 [1] 3961 (2020).

11. D. Kundu, B. D. Adams, V. Duffort, S. H. Vajargah and L. F. Nazar, "A High-Capacity and Long-Life Aqueous Rechargeable Zinc Battery Using a Metal Oxide Intercalation Cathode," Nat. Energy, 1 [10] 16119 (2016).

12. L. Wang, K.-W. Huang, J. Chen and J. Zheng, "Ultralong Cycle Stability of Aqueous Zinc-Ion Batteries with Zinc Vanadium Oxide Cathodes," Sci. Adv. 5 [10] eaax4279 (2019).

13. B. Wu, G. Zhang, M. Yan, T. Xiong, P. He, L. He, X. $\mathrm{Xu}$ and L. Mai, "Graphene Scroll-Coated $\alpha-\mathrm{MnO}_{2}$ Nanowires As High-Performance Cathode Materials for Aqueous Zn-Ion Battery," Small, 14 [13] 1703850 (2018).

14. N. Zhang, F. Cheng, Y. Liu, Q. Zhao, K. Lei, C. Chen, X. Liu and J. Chen, "Cation-Deficient Spinel $\mathrm{ZnMn}_{2} \mathrm{O}_{4}$ Cathode in $\mathrm{Zn}\left(\mathrm{CF}_{3} \mathrm{SO}_{3}\right)_{2}$ Electrolyte for Rechargeable Aqueous Zn-Ion Battery," J. Am. Chem. Soc., 138 [39] 12894-12901 (2016).

15. Y. Jin, L. Zou, L. Liu, M. H. Engelhard, R. L. Patel, Z. Nie, K. S. Han, Y. Shao, C. Wang, J. Zhu, H. Pan and J. Liu, "Joint Charge Storage for High-Rate Aqueous Zinc-Manganese Dioxide Batteries," Adv. Mater., 31 [29] 1900567 (2019).

16. S.-D. Han, N. N. Rajput, X. Qu, B. Pan, M. He, M. S. Ferrandon, C. Liao, K. A. Persson and A. K. Burrell, "Origin of Electrochemical, Structural, and Transport Properties in Nonaqueous Zinc Electrolytes," ACS Appl. Mater. Interfaces, 8 [5] 3021-3031 (2016).

17. H. Zhang, X. Liu, H. Li, B. Qin and S. Passerini, "High-Voltage Operation of a $\mathrm{V}_{2} \mathrm{O}_{5}$ Cathode in a Concentrated Gel Polymer Electrolyte for HighEnergy Aqueous Zinc Batteries," ACS Appl. Mater. Interfaces, 12 [13] 15305-15312 (2020).

18. W. J. Wruck, B. Reichman, K. R. Bullock and W. H. Kao, "Rechargeable $\mathrm{Zn}-\mathrm{MnO}_{2}$ Alkaline Batteries," $J$. Electrochem. Soc., 138 [12] 3560-3567 (1991).

19. J. Shin, J. Lee, Y. Park and J. W. Choi, “Aqueous Zinc 
Ion Batteries: Focus on Zinc Metal Anodes," Chem. Sci., 11 [8] 2028-2044 (2020).

20. B. Tang, L. Shan, S. Liang and J. Zhou, "Issues and Opportunities Facing Aqueous Zinc-Ion Batteries," Energy Environ. Sci., 12 [11] 3288-3304 (2019).

21. L. Kang, M. Cui, Z. Zhang and F. Jiang, "Rechargeable Aqueous Zinc-Ion Batteries with Mild Electrolytes: a Comprehensive Review," Batteries Supercaps, 3 [10] 966-1005 (2020).

22. W. Li, K. Wang, S. Cheng and K. Jiang, "A Long-Life Aqueous Zn-Ion Battery Based on $\mathrm{Na}_{3} \mathrm{~V}_{2}\left(\mathrm{PO}_{4}\right)_{2} \mathrm{~F}_{3}$ Cathode," Energy Stor. Mater., 15 14-21 (2018).

23. B. Zhang, Y. Liu, X. Wu, Y. Yang, Z. Chang, Z. Wen and Y. Wu, "An Aqueous Rechargeable Battery Based on Zinc Anode and $\mathrm{Na}_{0.95} \mathrm{MnO}_{2}$," ChemComm, 50 [10] 1209-1211 (2014).

24. G. M. Nolis, A. Adil, H. D. Yoo, L. Hu, R. D. Bayliss, S. H. Lapidus, L. Berkland, P. J. Phillips, J. W. Freeland, C. Kim, R. F. Klie and J. Cabana, "Electrochemical Reduction of a Spinel-Type Manganese Oxide Cathode in Aqueous Electrolytes with $\mathrm{Ca}^{2+}$ or $\mathrm{Zn}^{2+}$," J. Phys. Chem. C, 122 [8] 41824188 (2018).

25. M. S. Chae, J. W. Heo, H. H. Kwak, H. Lee and S.-T. Hong, "Organic Electrolyte-Based Rechargeable Zinc-Ion Batteries Using Potassium Nickel Hexacyanoferrate As a Cathode Material," J. Power Sources, 337 204-211 (2017).

26. Y. Zeng, X. Zhang, Y. Meng, M. Yu, J. Yi, Y. Wu, X. Lu and Y. Tong, "Achieving Ultrahigh Energy Density and Long Durability in a Flexible Rechargeable Quasi-Solid-State $\mathrm{Zn}-\mathrm{MnO}_{2}$ Battery," Adv. Mater., 29 [26] 1700274 (2017).

27. Z. Peng, Q. Wei, S. Tan, P. He, W. Luo, Q. An and L. Mai, "Novel Layered Iron Vanadate Cathode for High-Capacity Aqueous Rechargeable Zinc Batteries," Chem Comm, 54 [32] 4041-4044 (2018).

28. G. Zheng, C. Wang, A. Pei, J. Lopez, F. Shi, Z. Chen, A. D. Sendek, H.-W. Lee, Z. Lu, H. Schneider, M. M. Safont-Sempere, S. Chu, Z. Bao and Y. Cui, "HighPerformance Lithium Metal Negative Electrode with a Soft and Flowable Polymer Coating," ACS Energy Lett., 1 [6] 1247-1255 (2016).

29. H. Chen, H. Xu, B. Zheng, S. Wang, T. Huang, F. Guo, W. Gao and C. Gao, "Oxide Film Efficiently Suppresses Dendrite Growth in Aluminum-Ion
Battery," ACS Appl. Mater. Interfaces, 9 [27] 2262822634 (2017).

30. Q. Yang, Q. Li, Z. Liu, D. Wang, Y. Guo, X. Li, Y. Tang, H. Li, B. Dong and C. Zhi, "Dendrites in Zn-Based Batteries," Adv. Mater., 32 [48] 2001854 (2020).

31. M. C. H. McKubre and D. D. Macdonald, "The Dissolution and Passivation of Zinc in Concentrated Aqueous Hydroxide," J. Electrochem. Soc., 128 [3] 524-530 (1981).

32. Q. Yang, G. Liang, Y. Guo, Z. Liu, B. Yan, D. Wang, Z. Huang, X. Li, J. Fan and C. Zhi, "Do Zinc Dendrites Exist in Neutral Zinc Batteries: A Developed Electrohealing Strategy to In Situ Rescue In-Service Batteries," Adv. Mater., 31 [43] 1903778 (2019).

33. L. Chen, Z. Guo, Y. Xia and Y. Wang, "High-Voltage Aqueous Battery Approaching $3 \mathrm{~V}$ Using an AcidicAlkaline Double Electrolyte," ChemComm, 49 [22] 2204-2206 (2013).

34. L. Suo, O. Borodin, T. Gao, M. Olguin, J. Ho, X. Fan, C. Luo, C. Wang and K. Xu, "“'Water-in-Salt" Electrolyte Enables High-Voltage Aqueous LithiumIon Chemistries," Science, 350 [6263] 938 (2015).

35. F. Wang, O. Borodin, T. Gao, X. Fan, W. Sun, F. Han, A. Faraone, J. A. Dura, K. Xu and C. Wang, "Highly Reversible Zinc Metal Anode for Aqueous Batteries," Nat. Mater., 17 [6] 543-549 (2018).

36. C. Zhang, J. Holoubek, X. Wu, A. Daniyar, L. Zhu, C. Chen, D. P. Leonard, I. A. Rodríguez-Pérez, J.-X. Jiang, C. Fang and X. Ji, "A $\mathrm{ZnCl}_{2}$ Water-inSalt Electrolyte for a Reversible Zn Metal Anode," ChemComm, 54 [100] 14097-14099 (2018).

37. L. Zhang, I. A. Rodríguez-Pérez, H. Jiang, C. Zhang, D. P. Leonard, Q. Guo, W. Wang, S. Han, L. Wang and $\mathrm{X}$. Ji, " $\mathrm{ZnCl}_{2}$ "Water-in-Salt" Electrolyte Transforms the Performance of Vanadium Oxide as a Zn Battery Cathode," Adv. Funct. Mater., 29 [30] 1902653 (2019).

38. K. Wu, J. Huang, J. Yi, X. Liu, Y. Liu, Y. Wang, J. Zhang and Y. Xia, "Recent Advances in Polymer Electrolytes for Zinc Ion Batteries: Mechanisms, Properties, and Perspectives," Adv. Energy Mater., 10 [12] 1903977 (2020).

39. P. Heremans, A. K. Tripathi, A. de Jamblinne de Meux, E. C. P. Smits, B. Hou, G. Pourtois and G. H. 
Gelinck, "Mechanical and Electronic Properties of Thin-Film Transistors on Plastic, and Their Integration in Flexible Electronic Applications," Adv. Mater., 28 [22] 4266-4282 (2016).

40. A. Sepúlveda, J. Speulmanns and P. M. Vereecken, "Bending Impact on the Performance of a Flexible $\mathrm{Li}_{4} \mathrm{Ti}_{5} \mathrm{O}_{12}$-Based All-Solid-State Thin-Film Battery," Sci. Technol. Adv. Mater., 19 [1] 454-464 (2018).

41. J. P. Tafur and A. J. Fernández Romero, "Electrical and Spectroscopic Characterization of PVdF-HFP and TFSI-Ionic Liquids-Based Gel Polymer Electrolyte Membranes. Influence of $\mathrm{ZnTf}_{2}$ Salt," J. Membr. Sci., 469 499-506 (2014).

42. H. Ye and J. J. Xu, "Zinc Ion Conducting Polymer Electrolytes Based on Oligomeric Polyether/PVDFHFP Blends," J. Power Sources, 165 [2] 500-508 (2007).

43. H. Li, L. Ma, C. Han, Z. Wang, Z. Liu, Z. Tang and C. Zhi, "Advanced Rechargeable Zinc-Based Batteries: Recent Progress and Future Perspectives," Nano Energy, 62 550-587 (2019).

44. B. Chen, Z. Huang, X. Chen, Y. Zhao, Q. Xu, P. Long, S. Chen and X. Xu, "A New Composite Solid Electrolyte $\mathrm{PEO} / \mathrm{Li}_{10} \mathrm{GeP}_{2} \mathrm{~S}_{12} / \mathrm{SN}$ for All-Solid-State Lithium Battery," Electrochim. Acta, 210 905-914 (2016).

45. W. P. Hagan, R. J. Latham, R. G. Linford and S. L. Vickers, "Zinc Polymer Electrolytes in Battery Systems," Solid State Ion., 70-71 666-669 (1994).

46. P. Hiralal, S. Imaizumi, H. E. Unalan, H. Matsumoto, M. Minagawa, M. Rouvala, A. Tanioka and G. A. J. Amaratunga, "Nanomaterial-Enhanced All-Solid Flexible Zinc-Carbon Batteries," ACS Nano, 4 [5] 2730-2734 (2010).

47. S. Karan, T. B. Sahu, M. Sahu, Y. K. Mahipal and R. C. Agrawal, "Characterization of Ion Transport Property in Hot-Press Cast Solid Polymer Electrolyte (SPE) Films: [PEO: $\mathrm{Zn}\left(\mathrm{CF}_{3} \mathrm{SO}_{3}\right)_{2}$ ], Ionics, 23 [10] 2721-2726 (2017).

48. A. Becker, F. Katzen, A. Pühler and L. Ielpi, "Xanthan Gum Biosynthesis and Application: a Biochemical/ Genetic Perspective," Appl. Microbiol. Biotechnol., 50 [2] 145-152 (1998).

49. B. Katzbauer, "Properties and Applications of Xanthan Gum," Polym. Degrad. Stab., 59 [1] 81-84 (1998).
50. S. Ghorai, A. Sarkar, M. Raoufi, A. B. Panda, H. Schönherr and S. Pal, "Enhanced Removal of Methylene Blue and Methyl Violet Dyes from Aqueous Solution Using a Nanocomposite of Hydrolyzed Polyacrylamide Grafted Xanthan Gum and Incorporated Nanosilica," ACS Appl. Mater. Interfaces, 6 [7] 4766-4777 (2014).

51. S. Zhang, N. Yu, S. Zeng, S. Zhou, M. Chen, J. Di and Q. Li, "An Adaptive and Stable Bio-Electrolyte for Rechargeable Zn-Ion Batteries," J. Mater. Chem. A, 6 [26] 12237-12243 (2018).

52. Y. Chen, J. Zhao and Y. Wang, "Quasi-SolidState Zinc Ion Rechargeable Batteries for Subzero Temperature Applications," ACS Appl. Energy Mater. 3 [9] 9058-9065 (2020).

53. D. F. Vieira, C. O. Avellaneda and A. Pawlicka, "Conductivity Study of a Gelatin-Based Polymer Electrolyte," Electrochim. Acta, 53 [4] 1404-1408 (2007).

54. A. Turković, M. Pavlović, P. Dubček, M. LučićLavčević, B. Etlinger and S. Bernstorff, "SAXS/DSC Study of Polymer Electrolyte for Zn Rechargeable Nanostructured Galvanic Cells," J. Electrochem. Soc., 154 [6] A554 (2007).

55. C. Kim, B. T. N. Ngoc, K. S. Yang, M. Kojima, Y. A. Kim, Y. J. Kim, M. Endo and S. C. Yang, "Self-Sustained Thin Webs Consisting of Porous Carbon Nanofibers for Supercapacitors via the Electrospinning of Polyacrylonitrile Solutions Containing Zinc Chloride," Adv. Mater., 19 [17] 23412346 (2007).

56. S.-W. Kuo, C.-H. Wu and F.-C. Chang, "Thermal Properties, Interactions, Morphologies, and Conductivity Behavior in Blends of Poly(vinylpyridine)s and Zinc Perchlorate," Macromolecules, 37 [1] 192-200 (2004).

57. K. Xie and B. Wei, "Materials and Structures for Stretchable Energy Storage and Conversion Devices," Adv. Mater., 26 [22] 3592-3617 (2014).

58. N. A. Choudhury, S. Sampath and A. K. Shukla, "Gelatin Hydrogel Electrolytes and Their Application to Electrochemical Supercapacitors," J. Electrochem. Soc., 155 [1] A74 (2008).

59. D. Pelc, S. Marion, M. Požek and M. Basletić, "Role of Microscopic Phase Separation in Gelation of Aqueous Gelatin Solutions," Soft Matter, 10 [2] 348- 
356 (2014).

60. Q. Han, X. Chi, S. Zhang, Y. Liu, B. Zhou, J. Yang and Y. Liu, "Durable, Flexible Self-Standing Hydrogel Electrolytes Enabling High-Safety Rechargeable Solid-State Zinc Metal Batteries," J. Mater. Chem. A, 6 [45] 23046-23054 (2018).

61. Y. Lu, T. Zhu, N. Xu and K. Huang, "A Semisolid Electrolyte for Flexible Zn-Ion Batteries," ACS Appl. Energy Mater, 2 [9] 6904-6910 (2019).

62. W. Wieczorek and J. R. Stevens, "Proton Transport in Polyacrylamide Based Hydrogels Doped with $\mathrm{H}_{3} \mathrm{PO}_{4}$ or $\mathrm{H}_{2} \mathrm{SO}_{4}$," Polymer, 38 [9] 2057-2065 (1997).

63. S. Sumathi, V. Sethuprakash, W. J. Basirun, I. Zainol and M. Sookhakian, "PolyacrylamideMethanesulfonic Acid Gel Polymer Electrolytes for Tin-Air Battery," J. Sol-Gel Sci. Technol., 69 [3] 480487 (2014).

64. A. Virya and K. Lian, "Lithium PolyacrylatePolyacrylamide Blend As Polymer Electrolytes for Solid-State Electrochemical Capacitors," Electrochem. commun., 97 77-81 (2018).

65. H. Li, C. Han, Y. Huang, Y. Huang, M. Zhu, Z. Pei, Q. Xue, Z. Wang, Z. Liu, Z. Tang, Y. Wang, F. Kang, B. Li and C. Zhi, "An Extremely Safe and Wearable solid-State Zinc Ion Battery Based on a Hierarchical Structured Polymer Electrolyte," Energy Environ. Sci., 11 [4] 941-951 (2018).

66. W. Deng, Z. Zhou, Y. Li, M. Zhang, X. Yuan, J. Hu, Z. Li, C. Li and R. Li, "High-Capacity Layered Magnesium Vanadate with Concentrated Gel Electrolyte toward High-Performance and WideTemperature Zinc-Ion Battery," ACS Nano, 14 [11] 15776-15785 (2020).

67. H. Li, Z. Liu, G. Liang, Y. Huang, Y. Huang, M. Zhu, Z. Pei, Q. Xue, Z. Tang, Y. Wang, B. Li and C. Zhi, "Waterproof and Tailorable Elastic Rechargeable Yarn Zinc Ion Batteries by a Cross-Linked Polyacrylamide Electrolyte," ACS Nano, 12 [4] 3140-3148 (2018).

68. H. Li, Q. Yang, F. Mo, G. Liang, Z. Liu, Z. Tang, L. Ma, J. Liu, Z. Shi and C. Zhi, "MoS 2 Nanosheets with Expanded Interlayer Spacing for Rechargeable Aqueous Zn-Ion Batteries,” Energy Stor. Mater., 19 94-101 (2019).

69. T. Jiao, Q. Yang, S. Wu, Z. Wang, D. Chen, D. Shen, B. Liu, J. Cheng, H. Li, L. Ma, C. Zhi and W. Zhang, "Binder-Free Hierarchical $\mathrm{VS}_{2}$ Electrodes for High-
Performance Aqueous Zn Ion Batteries towards Commercial Level Mass Loading," J. Mater. Chem. A, 7 [27] 16330-16338 (2019).

70. G. G. Kumar and S. Sampath, "Electrochemical Characterization of Poly(vinylidenefluoride)-Zinc Triflate Gel Polymer Electrolyte and Its Application in Solid-State Zinc Batteries," Solid State Ion., 160 [3] 289-300 (2003).

71. J. J. Xu, H. Ye and J. Huang, "Novel Zinc Ion Conducting Polymer Gel Electrolytes Based on Ionic Liquids," Electrochem. commun., 7 [12] 1309-1317 (2005).

72. C. W. Lee, K. Sathiyanarayanan, S. W. Eom, H. S. Kim and M. S. Yun, "Novel Electrochemical Behavior of Zinc Anodes in Zinc/Air Batteries in the Presence of Additives," J. Power Sources, 159 [2] 1474-1477 (2006).

73. W. Lu, C. Xie, H. Zhang and X. Li, "Inhibition of Zinc Dendrite Growth in Zinc-Based Batteries," ChemSusChem, 11 [23] 3996-4006 (2018).

74. Z. Liu, T. Cui, G. Pulletikurthi, A. Lahiri, T. Carstens, M. Olschewski and F. Endres, "Dendrite-Free Nanocrystalline Zinc Electrodeposition from an Ionic Liquid Containing Nickel Triflate for Rechargeable Zn-Based Batteries," Angew. Chem. Int. Ed., 55 [8] 2889-2893 (2016).

75. J. M. Wang, L. Zhang, C. Zhang and J. Q. Zhang, "Effects of Bismuth Ion and Tetrabutylammonium Bromide on the Dendritic Growth of Zinc in Alkaline Zincate Solutions," J. Power Sources, 102 [1] 139143 (2001).

76. C. W. Lee, K. Sathiyanarayanan, S. W. Eom, H. S. Kim and M. S. Yun, "Effect of Additives on the Electrochemical Behaviour of Zinc Anodes for Zinc/ Air Fuel Cells," J. Power Sources, 160 [1] 161-164 (2006).

77. L. Zhu, H. Zhang, W. Li and H. Liu, "New Modification Procedure of Zinc Powder in Neodymium Nitrate Solution for Improving the Electrochemical Properties of Alkaline Zinc Electrodes," J. Phys. Chem. Solids, 70 [1] 45-54 (2009).

78. F. Wan, L. Zhang, X. Dai, X. Wang, Z. Niu and J. Chen, “Aqueous Rechargeable Zinc/Sodium Vanadate Natteries with Enhanced Performance from Simultaneous Insertion of Dual Carriers," Nat. 
Commun., 9 [1] 1656 (2018).

79. Q. Zhang, J. Luan, L. Fu, S. Wu, Y. Tang, X. Ji and H. Wang, "The Three-Dimensional Dendrite-Free Zinc Anode on a Copper Mesh with a Zinc-Oriented Polyacrylamide Electrolyte Additive," Angew. Chem. Int. Ed., 58 [44] 15841-15847 (2019).

80. W. Xu, K. Zhao, W. Huo, Y. Wang, G. Yao, X. Gu, H.
Cheng, L. Mai, C. Hu and X. Wang, "Diethyl Ether As self-Healing Electrolyte Additive Enabled LongLife Rechargeable Aqueous Zinc Ion Batteries," Nano Energy, 62 275-281 (2019).

81. L. Cao, D. Li, E. Hu, J. Xu, T. Deng, L. Ma, Y. Wang, X.-Q. Yang and C. Wang, "Solvation Structure Design for Aqueous Zn Metal Batteries," J. Am. Chem. Soc., 142 [51] 21404-21409 (2020).

\section{으조 창 신}

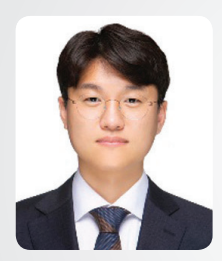

- 2007년-2016년 포항공과대학교 화학공학과 학사, 박사

○ 2017년-2018년 University of Cambridge, Research Associate

○ 2018년-2020년 University of Cambridge, Marie-Curie Fellow

- 2020 년 - 현재 중앙대학교 화학신소재공학부 조교수

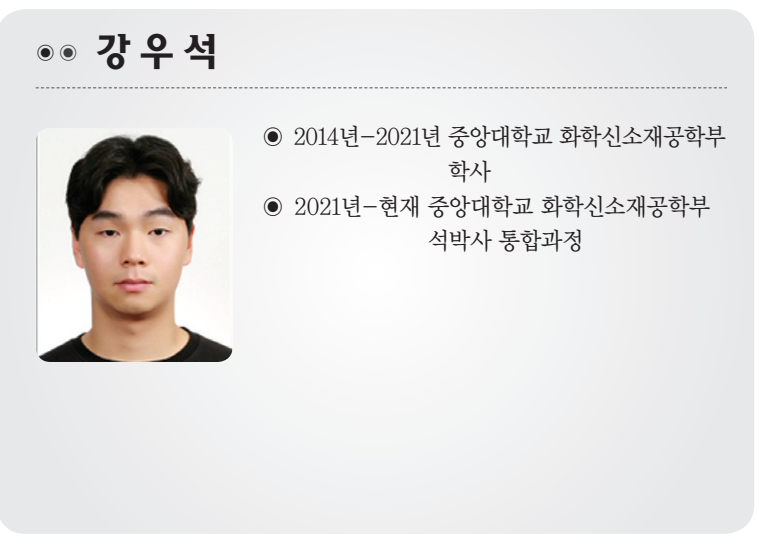

